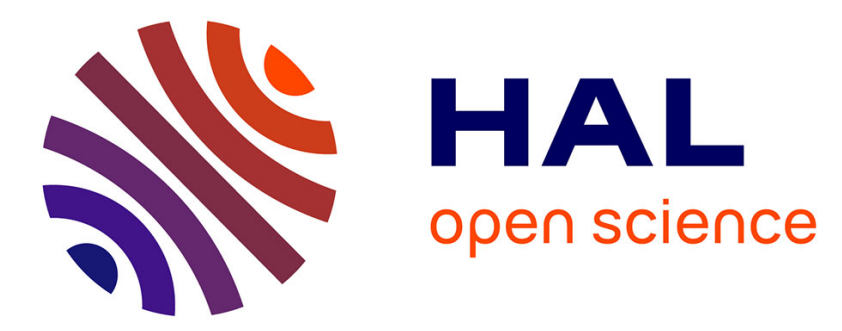

\title{
Ambient noise tomography of the western Corinth Rift, Greece
}

Dimitrios Giannopoulos, Diane Rivet, Efthimios Sokos, Anne Deschamps, Aurelien Mordret, Hélène Lyon-Caen, Pascal Bernard, Paraskevas

Paraskevopoulos, G-Akis Tselentis

\section{To cite this version:}

Dimitrios Giannopoulos, Diane Rivet, Efthimios Sokos, Anne Deschamps, Aurelien Mordret, et al.. Ambient noise tomography of the western Corinth Rift, Greece. Geophysical Journal International, 2017, 10.1093/gji/ggx298 . hal-01572605

\section{HAL Id: hal-01572605 https://hal.science/hal-01572605}

Submitted on 7 Aug 2017

HAL is a multi-disciplinary open access archive for the deposit and dissemination of scientific research documents, whether they are published or not. The documents may come from teaching and research institutions in France or abroad, or from public or private research centers.
L'archive ouverte pluridisciplinaire HAL, est destinée au dépôt et à la diffusion de documents scientifiques de niveau recherche, publiés ou non, émanant des établissements d'enseignement et de recherche français ou étrangers, des laboratoires publics ou privés. 


\section{Ambient noise tomography of the western Corinth Rift, Greece}

Dimitrios Giannopoulos ${ }^{1}$, Diane Rivet ${ }^{2}$, Efthimios Sokos ${ }^{1}$, Anne Deschamps ${ }^{2}$, Aurelien Mordret ${ }^{3}$, Hélène Lyon-Caen ${ }^{4}$, Pascal Bernard ${ }^{5}$, Paraskevas Paraskevopoulos ${ }^{1}$, G-Akis Tselentis ${ }^{1,6}$

${ }^{1}$ Seismological Laboratory, Department of Geology, University of Patras, Patras, Rio, Greece. E-mail: dgiannopoulos@upatras.gr

${ }^{2}$ Université Côte d'Azur, OCA, CNRS, IRD, Géoazur, France

${ }^{3}$ Department of Earth, Atmospheric and Planetary Science, MIT, Cambridge, MA 02139, USA

${ }^{4}$ Laboratoire de Géologie, Ecole Normale Supérieure/ UMR 8538 CNRS, PSL research university, Paris, 75005, France

${ }^{5}$ Laboratoire de Sismologie, Institut de Physique du Globe de Paris, CNRS, Paris, France

${ }^{6}$ National Observatory of Athens - Geodynamic Institute, Athens, Greece

Page heading: Corinth Rift ambient noise tomography

Corresponding author: Dimitrios Giannopoulos, University of Patras, Department of Geology, Laboratory of Seismology, 26504, University Campus, Rio, Greece, tel.: +30-2610-969369, fax: +302610-990639, e-mail: dgiannopoulos@ upatras.gr 


\section{SUMMARY}

Three years of continuous waveform data recorded at 22 stations from the Corinth Rift Laboratory and the Hellenic Unified Seismological Network are used to perform an ambient noise surface-wave tomography of the western Corinth Rift. All available vertical component time-series were crosscorrelated to extract empirical Rayleigh-wave Green's functions. Group velocity dispersion curves were measured for each station-pair by applying frequency-time analysis and then inverted to build 2D group velocity maps between 1 and 6 s period. Finally, we locally inverted these velocity maps using a neighborhood algorithm to assess the 3D shear-velocity model of the shallow crustal structure of the western Corinth Rift. Across all studied periods the southern coast of the Corinth Gulf is generally imaged as a region of lower velocities compared to the northern coast. At periods up to $3 \mathrm{~s}$, the spatial variation of the group velocities is correlated with the surface geology of the area. Lower velocities are observed in areas where mostly Plio-Quaternary syn-rift sediments are present, such as off-shore regions of the rift, the Mornos delta and the largest part of the southern coast. Higher velocities are observed in pre-rift basement structures which are dominated mostly by carbonates. At periods above $3 \mathrm{~s}$, where Rayleigh-waves begin to sense deeper structures below the sediments within the underlying basement, our study highlights the presence of a distinct zone of lower velocities across the southern part of the rift with an elongation in the WNW-ESE direction. The interpretation of this low velocity includes two arguments, the present-day active tectonic regime and the possible involvement of fluids circulation processes at depth within a highly fractured upper crust in the vicinity of the major faults zones. In general, the results demonstrate good agreement with the major geological and tectonic features of the area, as well as with previous local earthquake tomography studies and support the assumption of fluid circulations at depth. This work intends to be the base for further investigations towards the study of the Corinth Rift structure using long-time series of ambient noise data.

Keywords: Seismic tomography; Interferometry; Crustal structure; Corinth 


\section{INTRODUCTION}

During the last decade, surface-wave tomography using ambient seismic noise, commonly called ambient noise tomography, became an increasingly well established tool to constrain the seismic velocity structure of the Earth's lithosphere. Ambient noise tomography is based on the theory that the cross-correlation (CC) of ambient seismic noise recorded at two stations yields a deterministic wavelet, which is an approximation of the Green's function of the medium between the two stations. The retrieved empirical Green's function represents an approximation of the seismic response as if one of the two stations was acting as an impulsive source (e.g. Claerbout 1968; Lobkis \& Weaver 2001; Campillo \& Paul 2003; Shapiro \& Campillo 2004; Wapenaar 2004; Cutris et al. 2006). Since the retrieved Green's function carries the signature of the velocity structure between the stations, the interstation travel-times for surface-waves on multiple paths within a seismic network can then be used in a tomographic inversion to image the seismic velocity perturbations across the network. Ambient noise tomography has been widely applied for imaging the velocity structure at regional (e.g. Shapiro et al. 2005; Sabra et al. 2005) and continental (e.g. Yang et al. 2007; Bensen et al. 2008) scale and more recently at local scale (e.g. Brenguier et al. 2007; Mordret et al. 2015; Obermann et al. 2016, especially for imaging volcanic edifices). One of the principal advantages of ambient noise tomography relies on the fact that it is independent of the spatio-temporal distribution of seismicity. It provides in some cases a much needed alternative to traditional earthquake tomography in aseismic areas (e.g. continental interiors). In addition, it can provide complementary geophysical information for the shallow crustal structures, which cannot be well resolved with classical body-wave tomography.

The Corinth Rift in Greece is an active intra-continental rift on the western edge of the Aegean Arc (Fig. 1). During the past three decades, a considerable amount of multidisciplinary studies have been carried out to investigate the tectonic evolution and the mechanisms related to the deformation and seismicity of the Corinth Rift (e.g., Rigo et al. 1996; Lambotte et al. 2014). The significant scientific 
interest for this area is mainly due to its high extension rate (e.g., Briole et al. 2000; Avallone et al. 2004; Bernard et al. 2006) accompanied by frequent earthquake swarms (e.g. Lyon-Caen et al. 2004; Chouliaras et al. 2015; Kapetanidis et al. 2015) and moderate to large earthquakes (e.g. Hatzfeld et al. 1996; Bernard et al. 1997; Sokos et al. 2012). Despite the large amount of multidisciplinary observations and the proposed tectonic models, there is still an open discussion concerning the relationship between seismic activity at depth, fault mechanics and the rifting process (e.g., Rigo et al. 1996; Sorel 2000; Hatzfeld et al. 2000; Lambotte et al. 2014).

This work represents a first attempt to study the crustal velocity structure of the western Corinth Rift by performing a local-scale ambient noise tomography. In the framework of the ongoing research aimed at better constraining the shallow crustal structures of the Corinth Rift, ambient seismic noise tomography can provide complementary information in addition to either P- and S-waves local tomography (e.g. Latorre et al. 2004; Gautier et al. 2006) or marine seismic reflection surveys (e.g. Bell et al. 2008; Zelt et al. 2004; Taylor et al. 2011 among other) which have been performed in the western Corinth Rift. This complementary contribution of ambient noise tomography is based on the fact that, in the case of local body-wave tomography, surface layers are poorly constrained, in particular for the considered area partially covered by water. Despite the fact that the resolution of ambient noise tomography is lower than seismic reflection profiling, the first has the advantage to produce continuous onshore-offshore images of the shallow structures. Furthermore, better constraints on the shallow velocity structures would help to construct more reliable velocity models, something which could be of major importance toward the improvement of the seismic hazard assessments of this densely populated region.

In Section 2, we discuss the geodynamic setting of the Corinth Rift. In Section 3, we present the data, the pre-processing to compute the cross-correlations and the ambient noise Rayleigh-wave 
tomography of the western Corinth Rift. In Section 4, we discuss our results in the context of the rift's tectonics and geology and compare them with previous earthquake tomography studies of the area.

\section{GEODYNAMIC SETTING OF THE CORINTH RIFT}

The Corinth Rift separates main-land Greece to the north from Peloponnesus to the south (Fig. 1). It is approximately $120 \mathrm{~km}$ long and 10-20 km wide, with a WNW-ESE orientation, extending from the Gulf of Patras in the west, to the Gulf of Alkionides in the east. The Corinth Rift is considered as a site of major importance for earthquake studies as it is one of the most seismically active extensional rifts in the Euro-Mediterranean region (Armijo et al. 1996), with geodetically measured rates of extension varying from $\sim 5 \mathrm{~mm} / \mathrm{yr}$ at the eastern part to $\sim 15 \mathrm{~mm} / \mathrm{yr}$ at the western part and localized on a 10-20km wide zone (e.g., Briole et al. 2000; Avallone et al. 2004; Bernard et al. 2006). Several studies have been carried out investigating the cause of the high strain rates in the Corinth Rift. Some researchers have linked the rift formation to the westward motion of the Anatolian micro-plate and the propagation of the North Anatolian fault (e.g., Jackson 1994; Le-Pichon et al. 1995). Other studies related the rift formation to the roll-back of the subducting African plate (e.g., Le-Pichon \& Angelier 1979; Hatzfeld et al. 1997) and others to a combination of the previous processes (e.g., McClusky et al. 2000; Doutsos \& Kokkalas 2001). GPS measurements (e.g. Briole et al. 2000; Avallone et al. 2004; Bernard et al. 2006), earthquake focal mechanisms (e.g., Rigo et al. 1996; Bernard et al. 1997; Godano et al. 2014), as well as neo-tectonic faults analyses (e.g., Jackson et al. 1982; Doutsos \& Poulimenos 1992) indicate an approximately N-S direction of extension. The high strain rate in the Corinth Rift, especially at the western part, is accompanied by a high level of seismic activity which is characterized by frequent earthquake swarms and also by the occurrence of moderate and large earthquakes (Bourouis \& Cornet 2009). Even though the Corinth Gulf is geographically limited, a considerable number of on- and offshore earthquakes with magnitudes up to 7 were instrumentally recorded or historically reported (Papadopoulos 2000). Some characteristic cases of large and 
destructive earthquakes occurred during the last three decades are the Alkionides seismic sequence in 1981 involving three strong events of $\mathrm{M}_{\mathrm{S}}$ 6.7, 6.4 and 6.4 (Jackson et al. 1982), the $\mathrm{M}_{\mathrm{S}} 5.9$ Galaxidi earthquake in 1992 (Hatzfeld et al. 1996), the $\mathrm{M}_{\mathrm{S}} 5.4$ Patras earthquake in 1993 (Tselentis et al. 1994; Karakostas et al. 1994) and the $\mathrm{M}_{\mathrm{S}} 6.2$ Aigion earthquake in 1995 (Tselentis et al. 1996; Bernard et al. 1997).The Corinth Rift has major north-dipping normal faults located on the southern margins and minor antithetic south-dipping faults on the northern margins. The major north-dipping faults are organized in a right-stepping en echelon pattern with a strike that ranges between W-E and WNWESE with a steep dip of $55^{\circ}-70^{\circ}$, resulting in the subsidence of the northern coast and in the upward displacement of the main footwalls (Armijo et al. 1996). This is the case of the Eliki-Aigion-KamaraiPsathopyrgos fault system (Fig. 1), which is one of the youngest fault systems in the Corinth Rift, related to the opening phase of the gulf that initiated during Pliocene (Micarelli et al. 2003; Hamelsdaël \& Ford 2014).

Even though the Corinth Rift has been studied extensively and many tectonic models have been proposed, the understanding of the crustal structure is such that the relationship between major faults and seismicity at depth is still an open debate. Regarding the fault geometry four main models have been proposed, among others. For instance, Rigo et al. (1996), following King et al. (1985) and Doutsos \& Poulimenos (1992), proposed that the micro-seismicity is related to a low-angle seismically active detachment zone lying at $~ 9-11 \mathrm{~km}$ depth. According to Rigo et al. (1996) microseismicity in the western part of the Corinth Rift mainly occurs at the intersection between the major north-dipping normal faults that crop out along the southern part of the rift and the low-angle $\left(15^{\circ}\right.$ $\pm 10^{\circ}$ ) north-dipping detachment zone (see fig. 12 in Rigo et al. 1996). On the contrary, Sorel (2000) suggested a model according to which an active low-angle detachment fault, more than $70 \mathrm{~km}$ long, represents the major extensional structure of the Corinth Rift (Khelmos detachment, see fig. 3 of Sorel 2000), whereas the other north-dipping normal faults cropping out on the Peloponnesus are considered secondary listric structures which intersect the Khelmos detachment at a relative shallow depth only. 
Hatzfeld et al. (2000) suggested that micro-seismicity is probably related to a seismic-aseismic (brittle-ductile) transition zone at $\sim 8-12 \mathrm{~km}$ depth resulted from the rapid extension rate of the western Corinth Rift, and not to the low-angle north-dipping active faults as previously proposed. More recently, Lambotte et al. (2014) proposed a new mechanical model of the rifting process, which involves a non-elastic uniform deformation at depth under the Corinth Rift's axis. According to this model, an aseismic N-S opening of the rift is coupled with the downward and northward growth of a yet immature detachment, not yet connected to the ductile lower crust, and contributes most of the opening rate measured from GPS at the surface. The reported seismicity fluctuation would possibly result from small strain instabilities, undetected by continuous GPS and possibly related to non stationary migration of fluid pulses.

The stratigraphy of the western Corinth Rift reflects the present-day and Plio-Quaternary tectonic processes. Limestone nappes are outcropping almost everywhere to the north, whereas to the south these nappes are covered by thick layers of conglomeratic deposits due to the rapid uplift. Several both on-shore (e.g., Roberts et al. 2009; Leeder et al. 2012; Ford et al. 2013) and off-shore studies (e.g., Sachpazi et al. 2003; Zelt et al. 2005; Lykousis et al. 2007; Bell et al. 2008, 2009; Taylor et al. 2011) have been conducted aiming to extract and quantify the syn-rift sedimentation structure of the Corinth Rift. For instance, multichannel 2D seismic profiles and high resolution 2D seismic data collected during the Maurice Ewing (EW0108) 2001 geophysical survey (Taylor et al. 2011) and the 1997 SEISGRECE survey (Sachpazi et al. 2003) constrained successfully the geometry of the main faults and the off-shore syn-rift succession of the rift. Hemelsdael \& Ford (2014) used on-shore sedimentary, structural and geomorphological data, as well as the off-shore seismic reflection data from the 2001 geophysical survey (Taylor et al. 2011) to perform a stratigraphic correlation between off-shore and on-shore domains in the Corinth Gulf's basin. The on-shore syn-rift sediments of the western and central Corinth Rift have been separated into three lithostratigraphic groups (Nixon et al. 2016 and references therein). A lower group characterized by alluvial to lacustrine sediments 
deposited in the late Pliocene, a middle group dominated by lacustrine fan deltas that built during a period of rift deepening and northward migration, and an upper group characterized by alternating marine and lacustrine sediments (e.g., Leeder et al. 2012; Ford et al. 2013). Up to about $2.5 \mathrm{~km}$ of syn-rift sediments have accumulated in the off-shore Corinth Rift. The off-shore syn-rift sediments include two main sedimentary units, a lower thick "early-rift" unit and a shallower "late-rift" unit (Taylor et al. 2011). These main sedimentary units are separated by a basin-wide unconformity, which is locally angular and marks an abrupt change in the seismic reflection character (Nixon et al. 2016).

In view of the above background, it is clear that more research is needed to better understand the structural framework of the Corinth Rift, and for this reason any additional tool to constrain the seismic velocity structure of the area, such as the ambient noise tomography presented in this study, may substantially contribute to the knowledge towards this direction.

\section{AMBIENT NOISE TOMOGRAPHY}

The ambient noise tomography of the western Corinth Rift was performed by adopting a three-step approach following Ritzwoller et al. (2011) and Mordret et al. (2014). First, we analyzed Rayleighwave empirical Green's functions emerging from cross-correlations of ambient seismic noise between all station pairs and measured the frequency-dependent group travel-times from every inter-station CC. Then, we inverted the surface-wave travel-times to build 2D group velocity maps of the study area at different periods. The final step was to invert Rayleigh wave group velocity maps in order to obtain the depth structure. The latter was performed by inverting regionalized dispersion curves (DCs) for a local 1D shear-velocity model in every cell of the geographical grid. 


\subsection{Data and CCs computation}

The raw data are 3 yrs (from January 2011 to December 2014) of continuous seismic recordings from 22 seismic stations located at the western Corinth Rift. We used the vertical component recordings from 11 broadband and 11 short-period seismic sensors maintained by the Corinth Rift Laboratory (CRL, http://crlab.eu/), the University of Patras Seismological Laboratory (UPSL, http://seismo.geology.upatras.gr/) and the Seismological Laboratory of Athens University (NKUA, http://dggsl.geol.uoa.gr/) (Fig. 2).

Prior to the computation of the CCs, a pre-processing was applied on 1-day long traces of seismic noise (raw data) including the following steps: (1) Removal of the mean and the trend of the signal, (2) decimation of the signal to $5 \mathrm{~Hz}$, (3) band-pass filtering between $0.07-2.5 \mathrm{~Hz}$, (4) removal of the instrumental response, (5) elimination of signal parts with amplitude greater than 10 times their standard deviation, (6) spectral whitening between $0.07-2.5 \mathrm{~Hz}$, (7) discarding signals with amplitude greater than 3 times their standard deviation and (8) one-bit normalization. This is a standard procedure including the instrumental response removal, applied to facilitate correlation of signals from broad band and short period instruments.

We computed daily cross-correlations of the pre-processed noise records between the vertical components of all possible station pairs (Fig. 2) and then we stacked all daily CCs over the whole recording period to extract the empirical Rayleigh-wave Green's functions. Finally, for each interstation CC, we merged the two-sided stacked signals into one-sided by averaging their positive and negative lag times.

In Fig. 3a and 3b, for the AGRP - PANR inter-stations path of $\sim 45 \mathrm{~km}$ and for the AGEO - AIOA path of $\sim 8 \mathrm{~km}$, the $\sim 3 \mathrm{yrs}$ cross-correlation functions were filtered in different period bands. We observe the dispersive character of the reconstructed Rayleigh-waves, with the longer period waves 
preceding the short period waves, for both long and short inter-station distances. The dominant frequency content of the cross-correlation functions between AGRP - PANR and AGEO - AIOA range between $0.15 \mathrm{~Hz}(\sim 6.6 \mathrm{~s})$ and $0.8 \mathrm{~Hz}(\sim 1.25 \mathrm{~s})$, and $0.15 \mathrm{~Hz}(\sim 6.6 \mathrm{~s})$ and $1.05 \mathrm{~Hz}(\sim 0.9 \mathrm{~s})$, respectively (Fig. 3c and 3d). The frequency contents and the Rayleigh-wave dispersion presented in Fig. 3 suggest that we can use the cross-correlation functions, having a sufficient vertical resolution to resolve the shallow velocity structure of the western Corinth Rift based on the analysis of the dispersion characteristics.

\subsection{Dispersion measurements}

We used the Frequency-Time Analysis (FTAN) technique (Levshin et al. 1989) to measure group velocities of surface-waves extracted from the vertical-vertical component CCs. Commonly, due to the large amount of data, the estimation of the group velocity DCs is performed automatically. However, in order to avoid in some cases an incorrect picking of the DC in the time-frequency diagram, i.e. possibly due to the presence of high-amplitude surface-wave's overtones, we used a Graphical Users Interface implemented by Mordret et al. (2014 \& 2015). It allows analyst contribution to the picking of the DCs and prevents possible false detections. Fig. 4 shows an example of DCs picking on the time-frequency diagrams for a vertical-vertical component correlation between stations EFP (broad band) and PSAR (short-period). The relative maxima of the diagrams corresponding to the fundamental mode and manually validated are interpolated and smoothed by a fifth-order polynomial. Every Rayleigh-wave DC that was measured and used for this study was plotted on a frequency-time diagram. The average DC with its standard deviation is presented (Fig. 5a). The number of measurements as a function of the period (Fig. 5b) indicates sufficient data availability across $\sim 1$ and $\sim 6 \mathrm{~s}$ periods. Then the probability density function of the DCs is calculated (Fig. 5c). 


\subsection{Rayleigh-wave group velocity maps}

For the tomographic inversion of the dispersion curves we followed the method for surface-wave tomography of Barmin et al. (2001) and more specifically we followed a Cartesian version of this method implemented by Mordret et al. (2013). The ray-theoretic method of Barmin et al. (2001) is mainly based on minimizing a regularization function composed of a Gaussian-shaped lateral smoothing function and a constraint on the amplitude of the perturbation weighted by local ray-path density. The methodology is described in detail in Mordret et al. (2013).

Taking into account the data availability per period, we tested different sizes of grid spacing to achieve the best compromise between models parameterization, spatial resolution and a reliable representation of the velocity features. After these tests we opted for the following inversion grid step by using two different grid spacing for the 2D group velocity models: for periods $\mathrm{T}<2 \mathrm{~s}$ and $\mathrm{T}>4 \mathrm{~s}$ we used a $17 \times 10$ grid with a cell size of $0.04^{\circ} \times 0.04^{\circ}(\sim 4.1 \mathrm{~km} \mathrm{EW}$ and $\sim 4.4 \mathrm{~km} \mathrm{NS})$ while for periods $2 \mathrm{~s} \leq \mathrm{T} \leq 4 \mathrm{~s}$ we used a denser $22 \times 17$ grid with a cell size of $0.03^{\circ} \times 0.03^{\circ}(\sim 3.1 \mathrm{~km} \mathrm{EW}$ and $\sim 3.3 \mathrm{~km} \mathrm{NS}$ ). We inverted the Rayleigh-wave group velocities at 26 periods between 1 and $6 \mathrm{~s}$ with a step of 0.2 s. Following Moschetti et al. (2007) and Mordret et al. (2015), we performed the inversion in two main steps. The initial model for the inversion is characterized by a constant velocity, which is taken as the mean group velocity for each period. In the first step, we inverted a very smooth map that was used to detect and exclude measurement outliers. We discarded measurements having travel-time residuals greater than two times the standard deviation. In the second step, we used the remaining measurements to build the final group velocity maps for each period. The resulted ray-path coverage (Fig. 6) shows a quite dense coverage at periods of 2 to $4 \mathrm{~s}$ while at 1 and $6 \mathrm{~s}$ the coverage is sparser.

During the inversion procedure the topography and the bathymetry of the rift were not taken into account. One could argue that the topography and the bathymetry of the study area could affect the accuracy of the measurements, especially the velocity measurements of short-period surface-waves. 
For this reason, following Mordret et al. (2015), we estimated the Rayleigh-wave velocity errors as the relative difference in distance between the stations with or without taking into account the relief of the area. The errors are thus the relative difference between the length of the horizontal line that connects each station-pair and the length of the line that follows the shape of the relief (including elevation and bathymetry) between the stations. We found errors $<1 \%$ (Fig. 7) on group velocity measurements, with more than $90 \%$ of the inter-station ray-paths having errors $<0.4 \%$. Considering the observed dispersion of the group velocity measurements per period (Fig. 5a), these estimated errors caused by the flat topography approximation should be definitely considered insignificant.

Maps of final 2D Rayleigh-wave group velocity models of the western Corinth Rift at six different periods from 1 to $6 \mathrm{~s}$ are presented in Fig. 8. The mean velocity appears to increase with increasing period from $\sim 1.4$ at $1 \mathrm{~s}$ to $\sim 2.2 \mathrm{~km} / \mathrm{s}$ at $6 \mathrm{~s}$. The mean velocity seems also to be in good agreement with the average of the DCs shown in Fig. 5a. The variance reduction of the travel-time residual is generally higher than $50 \%$, with an exception of the variance reduction at $1 \mathrm{~s}$ period, indicating that the derived velocity maps fit the data relatively well.

Concerning the resolution assessment of the group velocity maps, following Barmin et al. (2001) and Mordret et al. (2013; 2015), we assessed the spatial resolution of the group velocity maps evaluating the resolution matrix corresponding to each inversion. Each row of the resolution matrix is a resolution map defining the resolution at each cell of the model and more specifically, it represents the approximate response of the tomographic procedure to a Delta-function type perturbation in a specific cell of the grid. Using the resolution matrices at every cell, we fitted an ellipse to the respective resolution map that encloses $50 \%$ of the recovered amplitude and took its major axis as estimation for the spatial resolution. Figs. 9 and 10 show plots of the ray-path density and spatial resolution maps for the studied periods, respectively. 
Taking into account the geometry of the available seismic network and the ray-path coverage of the study area, the spatial resolution of the group velocity appears to be poor towards the eastern and western edges where only a small number of ray-paths or some isolated rays are available. The most characteristic case is the region between the Rion straits and the Mornos delta at the western edge of the study area (see Figs. 6 and 8-10). In some cases, the irregular distribution of available ray-paths causes minor smearing effects/artifacts in the mapped group velocity perturbation such as the observed velocity features at the corners of the easternmost edge (see Figs. 6 and 8-10).

\subsection{Depth Inversion}

All retrieved Rayleigh-wave group velocity maps can be considered as a set of local group velocity DCs. For each cell of the geographical grid one can collect group velocity measurements at different periods forming local DCs. The inversion of a local DC leads to a local 1D shear-velocity model and consequently the combination of all individual 1D models from all cells results in a 3D shear-velocity model of the sub-surface. For the needs of our study, we gathered the group velocities with the already used step of $0.02 \mathrm{~s}$ period in each model cell, using a grid of $30 \times 17$ cells and a cell size of $0.02^{\circ} \times$ $0.02^{\circ}$ to construct the local DCs.

Before inverting each local DC for the 3D structure, we calculated and inverted the average DC of the local dispersion curves in order to assess an average 1D shear-velocity model of the complete study area. For the inversion at depth we adopted the Neighborhood Algorithm, an optimized Monte-Carlo global search technique developed by Sambridge (1999a,b), which has been efficiently used in various geophysics inversions (e.g., Kao et al. 2013; Mordret et al. 2014; Yao 2015). This search algorithm makes use of geometrical constructs known as Voronoi cells to derive the search in a model-space. A model is a set of different parameters and the corresponding model-space is a multi-dimensional space having the same dimensions as the number of the parameters used to characterize the model. The model-space is specified by a priori range of values for each parameter. In the case of our local DC 
inversion problem, the model is a $1 \mathrm{D}$ layered shear-wave velocity profile with two parameters for each layer, the thickness and the shear-wave velocity. The methodology, the data misfit calculation and the algorithms we used for this study are described in detail in Mordret et al. (2014). For the average 1D shear-velocity profile of the whole study area, we parameterized the model with four layers over a half space with seven unknowns, the velocities in the four layers, as well as the depths of the first three associated interfaces. Concerning the fourth interface, we set the top of the half-space with a fixed value, much deeper than the expected sensitivity of the retrieved Rayleigh-waves we inverted. During this inversion 15000 models have been sampled. Results of the inversion for the average 1D shear-velocity model are presented in Fig. 11. One drawback of the above parameterization relies on the fact that when the dimensionality (number of parameters) of the parameter-space is increased, the basic random generation of models becomes quite inefficient. Testing with different number of parameters showed that as the number of parameters grows, the nonsingularity of the final solution becomes more and more critical and choosing the right model which has also a physical meaning during the sampling of the model-space was difficult. Due to this restriction, we choose to sample the model-space with a small number of layers (four), ensuing reliable results on the one hand, and images with slightly lower resolution on the other hand.

In the last step, we calculated and kept the best-fitting 1D depth profiles for every grid cell, resulting in a 3D shear-velocity model of the western Corinth Rift. From the resulted 3D structure, we were able to extract $1 \mathrm{D}$ profiles, as well as $2 \mathrm{D}$ vertical and horizontal sections at any desired location or depth, respectively. In Figs. 12 and 13 we show vertical 2D sections, an East-West (S1) and two North-South (S2 and S3), cutting through the study area, and horizontal slices at different depths (800, 2000, 3900 and $5100 \mathrm{~m})$, respectively.

We did not account for the western Corinth Rift relief in our analysis. Besides the previously mentioned negligible influence on the group velocities (Fig. 7), even for the lowest studied periods of 
around $1 \mathrm{~s}$, the wavelength is estimated to be longer than the elevation or the bathymetry of the western Corinth Rift $(\lambda(1 s)=c / f=1.44 \mathrm{~km})$. To eliminate a bias for the interpretation, the average velocity model that we determined for the area of interest (Fig. 11) was used to calculate the frequency dependent depth sensitivity (Herrmann 2013) of Rayleigh-waves at different periods between 1and $6 \mathrm{~s}$. The computed depth sensitivity kernels are presented in Fig. 14. We observe that Rayleigh-waves at periods around $1 \mathrm{~s}$ are sensitive to the upper $750 \mathrm{~m}$. Deeper parts of the subsurface are sampled by longer period Rayleigh-waves with larger wavelengths that are slightly affected by the topography. Hence we consider that Rayleigh-waves of larger periods are affected negligibly by the flat topography approximation and the retrieved velocity perturbations at depth are reliable.

\section{INTERPRETATION AND DISCUSSION}

\subsection{Rayleigh-wave group velocity maps}

Considering the resolution estimation at $1 \mathrm{~s}$ period (Fig. 10a), a reliable interpretation of the Rayleigwave group velocity map (Fig. 8a) can be made only for the eastern part of the study area, namely around Aigion, Trizonia and the region between them. The $2 \mathrm{~s}$ Rayleigh-wave group velocity map in Fig. 8b highlights two distinct low velocity zones. A low velocity zone around Aigion area in the southeast (which is also highlighted in the well-recovered part of the $1 \mathrm{~s}$ period map, Fig. 8a), and a second one around Psathopyrgos area in the southwest, which extends up to Mornos delta to the north. Higher velocities are imaged across the rest of the area, but mostly across the northern part of the rift. The lateral extent of the lower and higher velocity zones at periods around 1 and $2 \mathrm{~s}$ coincides quite well with the surface geology (see the generalized tectonic map in Fig. 1). The observed low velocities can be related to the presence of Plio-Quaternary syn-rift sediments on the south coast and around the Mornos delta, while higher velocities are related to the pre-rift basement structures that are outcropping to the north. The observed lateral expansion of the low velocity zones towards the offshore region between Mornos delta and Psathopyrgos, as well as towards the off-shore area north of 
Aigion can be associated to the sediments of deltaic sequences which are accumulated in the basin. Sedimentation in the Corinth Gulf (Late Quaternary) is mostly controlled by the sediment input from the surrounding rivers (Perissoratis et al. 2000). The largest rivers that are draining into the gulf are the aforementioned Mornos in the northwest and a series of several short steep rivers around the Aigion area, that enter the southern gulf draining the mountains of northern Peloponnesus. Deltaic sequences have been documented on both sides of the western margins of the rift, between the Mornos delta and Psathopyrgos (Perissoratis et al. 2000).

The 3 s Rayleigh-wave group velocity map (Fig. 8c) shows quite similar features as the $2 \mathrm{~s}$ map. In this case, the previously observed two low velocity anomalies tend to merge into a single WNW-ESE trending low velocity anomaly, extending continuously from the Aigion area to the Mornos delta. The overall distribution of the low velocities at $3 \mathrm{~s}$ still demonstrates good agreement with the major geological features of the area, reflecting also the asymmetric structure of the rift. As we expected, higher velocities at $3 \mathrm{~s}$ period are observed across the northern coast of the gulf, where pre-rift basement structures are present.

At periods above $3 \mathrm{~s}$, where group velocity measurements are sensitive to deeper structures of the crust, the dispersion maps in Figs. 8d to 8f highlight a lower group velocity zone with a more distinct preferential elongation in the WNW-SSE direction located in the southern part of the rift. The low velocity anomaly is the most profound feature in the velocity maps between 4 and $6 \mathrm{~s}$, which appears to shrink gradually with increasing period. The characteristic depth of penetration of the Rayleighwaves can be roughly considered wavelength-dependent. Assuming that the depth of the maximum sensitivity of Rayleigh-waves ranges approximately between one-third and one-half of their wavelengths (Lowrie 2007), and considering also the estimated mean velocities of the emerged Rayleigh-waves (shown at the lower left corner of each frame of Fig. 8), Rayleigh-waves of 4 s period for instance, with a mean velocity of $\sim 2 \mathrm{~km} / \mathrm{s}$, would be sensitive down to $\sim 2.7-4 \mathrm{~km}$. In general, the 
longer the period, the deeper the Rayleigh-wave energy penetrates. Stratigraphic interpretation of onshore and offshore data of sedimentary and lithostratigraphic logs, 2D seismic reflection profiles etc., (e.g., Sachpazi et al. 2003; Lykousis et al. 2007; Bell et al. 2008, 2009; Taylor et al. 2011; Nixon et al. 2016) have revealed that the maximum thickness of the syn-rift sediments accumulated above the basement in the Corinth Rift is about $2.5 \mathrm{~km}$. The maximum thickness was measured in the central rift's basin, outside of our study area. The sediments thickness varies considerably along the $\sim \mathrm{E}-\mathrm{W}$ rift axis, and specifically, it has been indicated that sediments thicken from the west toward the eastern part of the basin (Sachpazi et al. 2003). Therefore, the thickness of the accumulated syn-rift sediments within our study area is expected to be quite smaller than the maximum reported one from the literature.

Rayleigh-waves at periods above $3 \mathrm{~s}$ should begin to sense the faster shear-wave velocities in the prerift carbonates within the underlying basement. So, seismic velocity features in the group velocity maps at periods above $3 \mathrm{~s}$ (Figs. 8d to 8f) most likely reflect the characteristics of the underlying basement.

Comparing also the orientation of the obtained low velocity anomaly with the orientation of the active normal faults at the southern coast as well as with the orientation of the overall rift axis, a striking similarity is observed between them. Taking into account all the group velocity maps across all the studied periods from 1 to $6 \mathrm{~s}$, we observe in general that the lower velocity anomaly around Aigion in the eastern part of the study area is bounded by the Trizonia fault in the north and by the west Heliki fault on the southern side.

\subsection{Shear-wave velocities at depth}

Despite the fact that our resolution is not enough to detect sharp variations at depth, results and images from the depth inversion reveal the presence of some distinctive velocity patterns which, as 
would normally be expected, are in agreement with the results of the ambient noise tomography. According to the available local DCs extracted from the Rayleigh-wave group velocities, we were able to constrain the shear-velocity structure of the area up to $\sim 6 \mathrm{~km}$ depth, considering the upper 4 $\mathrm{km}$ of the crust as the well resolved parts.

Vertical cross-sections and map views of the shear-wave velocity distribution (Fig. 12 and 13) show the presence of low velocity regions which correlate relatively well with the low velocity Rayleigh wave group velocity regions obtained from the noise tomography maps, providing better constraints on the depth distribution of the detected low velocity zones. These low velocity zones are located beneath the southern part of the rift, while their lateral expansion confirms their already mentioned spatial correlation with the major fault traces of the area. More specifically, low velocities across the E-W profile S1 (Fig. 12a) are clearly related with the Psathopyrgos fault and the western edge of the Kamarai/Selianitika fault zones. In the N-S profile S2 (Fig. 12b) we distinctly observe a region of lower velocities in the vicinity of the East Eliki, Aigion and Kamarai/Selianitika faults. Profile S3 presents similar velocity patterns in the N-S direction around the Psathopyrgos fault as in S1. Slices through the well-recovered parts of the 3D shear-velocity model at different depths provide a better picture about the distribution of the observed low velocity zones as depth increases. The horizontal sections (Fig. 13) clearly illustrate the WNW-ESE elongated low velocity zone across the southern margins of the rift. Notably, this zone is clearly observed not only beneath the Corinth Gulf, but also beneath the northern Peloponnesus, even within the deeper part of the crust, much deeper than the estimated total thickness of the sediments. Note for instance, the strong lateral variation of shearvelocities at $5100 \mathrm{~m}$ depth (Fig. 13d), where the lowest shear-velocity values are detected beneath the Aigion area.

It is worth noting at this point that the derived shear-velocities from the current study by means of ambient-noise interferometry are in general quite lower than previous $\mathrm{V}_{\mathrm{S}}$ models proposed for the 
same region, and particularly those derived from local travel-time measurements. Such crustal models are the corresponding models proposed by Rigo et al. (1996) and Latorre et al. (2004) for the western Corinth Rift. On the contrary, the observed $\mathrm{V}_{\mathrm{S}}$ model from the current study displays higher values in the uppermost layers of the crust compared with that proposed by Novotny et al. (2000) inferred from surface-waves, but at depths greater than $\sim 3 \mathrm{~km}$, our model presents lower $\mathrm{V}_{\mathrm{S}}$ values. In Fig. 15 we present the average 1D Vs model derived from the present study, along with the aforementioned crustal models of Rigo et al. (1996), Latorre et al. (2004) and Novotny et al. (2000) up to $\sim 6 \mathrm{~km}$ depth. Among other possible factors (i.e., different methodologies), the lower shear-velocities of our model compared with those of Rigo et al. (1996) and Latorre et al. (2004) are most probably due to the high sensitivity of the Rayleigh-wave propagation velocity, especially of the low period Rayleighwaves, to the very shallow structures of sediment depositions in the study area. This is also supported by the lower $V_{S}$ values compared to that of Novotny et al. (2000) whose model was derived by joint inversion of both Love and Rayleigh-waves. Considering the fact that the 1D models of the Corinth Rift derived from measurements of first-arrival times usually suffer from a limited resolution in the shallower crust between depths of 0 and $4 \mathrm{~km}$ (Latorre et al. 2004), Ambient Noise Tomography possibly contributes to a more reliable understanding of the shallow structures of the crust by providing a crustal velocity model at a resolution higher than those attainable by travel-time tomography alone.

\subsection{Overall Interpretation}

Since no other ambient noise tomography studies of our target area are available in the literature, we compare our results with those obtained by the tomographic studies of Gautier et al. (2006) and Latorre et al. (2004). In both studies a three-dimensional travel-time tomography of the western Corinth Rift was performed by re-analyzing data sets of passive seismological experiments. The outcome of the previous works was among others, the construction of detailed shear-wave velocity images down to $\sim 11 \mathrm{~km}$ of the western Corinth Rift. Large-scale features of our models are similar to 
those obtained by the Latorre et al. (2004) and Gautier et al. (2006). In Gautier et al. (2006), the authors both detected a low velocity region parallel to the trend of the rift. In Fig. 16 we show map views up to $5 \mathrm{~km}$ depth of the tomographic models modified from Latorre et al. (2004) and Gautier et al. (2006). The detected low velocity anomaly from the previous studies shows a similar orientation and evolution with increasing depth, being in agreement with the observations from our ambient noise tomography models. On the southern coast, the lower velocities are spatially correlated with the major fault traces, such as the Heliki, Aigion, and Kamarai/Selianitika faults, an observation which is also supported by the previous studies. In the first instance, following Gautier et al. (2006) and Latorre et al. (2004), we suggest that the distribution of the lower velocities is possibly controlled by both the presence of the pre-rift deposits and the present-day active tectonic regime of the area. However, since the pre-rift sediments have a thickness varying from a few hundreds of meters to a maximum one of about $2.5 \mathrm{~km}$ northwards into the basin (Hamelsdaël \& Ford 2014), this is not sufficient to interpret this low velocity image at periods above $3 \mathrm{~s}$ affecting deeper parts of the crust, below the sediments. A possible complementary explanation for the presence of the distinct low velocity zone at the south would be that the upper crust is highly fractured allowing for fluid circulation.

Indeed, within the framework of the observatory of CRL (http://crlab.eu/) several multidisciplinary studies have been performed aiming to investigate the mechanics of the active faults in the western Corinth Rift with a special emphasis on the role of fluids. For instance, the study concerning the 1995 Aigion earthquake and its aftershocks (Bernard et al. 1997) has pointed out that either over-pressured fluids or stress rotations coming from crustal heterogeneities might have played a role in triggering the Aigion earthquake as well as other moderate earthquakes in the Corinth Rift. Bourouis \& Cornet (2009) indicated possible overpressure fluid diffusion processes in the western Corinth Rift, related to the seismically activated parts of the crust. The previous authors, using also the hydraulic data from a deep well that intersected the Aigion Fault (Cornet et al. 2004), suggested that the overpressure conditions within the normal fault system of the southern coast are possibly due to the fact that the 
faults act as hydraulic barriers in the direction perpendicular to their strike, preventing fluid flows. In the case of the Aigion fault, it has been shown that the fault core is made of a thick impermeable clay zone surrounded by permeable cataclastic zones. Existence of fluids in the cataclastic zones of faults in the western Corinth Rift has been also documented from geochemical analysis of fault gouges (Koukouvelas \& Papoulis 2009; Pick \& Marty 2008; Baus et al. 2004). Other studies that have indicated the presence of fluids in the area close to the observed low velocity zone and their key role in the development of seismicity are among others the already mentioned study of Latorre et al. (2004), according to which high $\mathrm{V}_{\mathrm{P}} / \mathrm{V}_{\mathrm{S}}$ ratios were recognized between 7 and $9 \mathrm{~km}$ depth under the rift indicating fluid saturated rocks and Pacchiani \& Lyon-Caen (2010) suggesting a fluid-driven spatio-temporal evolution of seismicity, studying the case of the 2001 Agios Ioannis earthquake swarm (located few $\mathrm{km}$ south of Aigion). The results of the ambient noise tomography maps at periods above $3 \mathrm{~s}$, and those of the 3D shear-velocity model depicting the presence of the distinct low velocity anomaly even at depths greater than $\sim 3 \mathrm{~km}$ (Fig. 13c and d) below the southern part of the Corinth Rift could confirm to some extent the observed evidence of over-pressured fluids and fluid circulation processes at depth. It seems that the proposed evidence of fluid circulation processes within a highly fracture medium are located deep into the pre-rift basement. A detailed analysis of Lambotte et al. (2014) has provided a better view of the relationship between the seismicity at depth and the active faults at the surface, revealing the complex internal structure of a seismically active, 1-3 km thick layer, between 5 and $9 \mathrm{~km}$ depth. According to Lambotte et al. (2014), the Eliki-AigionKamarai/Selianitika fault system roots in the microseismically active layer at about $7 \mathrm{~km}$ depth, with dips similar to the ones observed at the surface. The tomographic images by Gautier et al. (2006) in accordance with the previous study, point out that the microseismic activity is aligned along a NW-SE direction and is concentrated within the high $\mathrm{V}_{\mathrm{P}} / \mathrm{V}_{\mathrm{S}}$ anomalous zone at $7-9 \mathrm{~km}$ close to the bottom of the aforementioned microseismic layer. The low velocity zone obtained from our analysis is objectively too shallow to be related to the microseismic layer at depth, however, a recent study of the spatiotemporal characteristics of the 2003-2004 seismic swarm in the western Corinth Rift by 
Duverger et al. (2015), provided evidence for pore pressure diffusion processes along a permeable fault system, suggesting that the intersection of the Aigion-Kamarai fault system with the seismically active layer possibly creates a hydraulic connection between deeper fluid sources and the bottom of the fault planes. It seems that the WNW-ESE direction of the observed low velocity zone is quite consistent with both the strike of the neighboring major fault traces and the distribution of the microseismic activity at depth, reflecting the presence of permeable and highly fractured parts in the upper crust along the southern coast of the rift. In general, our findings support the hypothesis of fluid interactions and their significant role to the overall evolution of the rift proposed by previous research studies in the literature.

\section{CONCLUSIONS}

Ambient noise recordings were used for the first time to study the velocity structure of the western Corinth Rift. Continuous vertical-component ambient noise data obtained between 2012 January $1^{\text {st }}$ and 2014 December $31^{\text {st }}$ recorded by 22 stations of CRL and HUSN networks were used to build 2D Rayleigh-wave group velocity maps and asses the 3D shear-velocity structure. Despite the fact that our resolution was not enough to detect sharp variations, the results reveal the presence of distinctive velocity features. The tomography maps clearly evidence an asymmetric velocity structure of the western Corinth Rift with the southern margin slower than the northern one, being in agreement with previous earthquake tomography studies. The velocity variations observed at periods below $3 \mathrm{~s}$ are mostly due to lithological variation. We suggest that the presence of a low velocity anomaly below the southern part of the rift is related to the present-day active tectonic regime reflecting possible involvement of fluid circulation processes at depth within a highly fractured upper crust.

This study emphasizes the usefulness of the ambient seismic noise technique as an additional tool towards the investigation of the Corinth Rift's evolution and we efficiently showed the potential to use 
ambient seismic noise recordings for Ambient Noise Tomography at a local scale within a complex geotectonic environment such as the Corinth Rift. A denser and extended seismic network made of broadband sensors around the western Corinth Rift is however required in order to achieve more accurate images of smaller scale features of both shallow and deep part of the crust, and also to widen the frequency range of the reconstructed surface-waves and the Ambient Noise Tomography. Following the previous suggestion, adding some ocean bottom seismometers in the center of the Corinth Rift's basin would greatly increase the area coverage (ray-path coverage) and the resolving potential of Ambient Noise Tomography eliminating some uncertainty in our observations.

\section{ACKNOWLEDGEMENTS}

We are grateful for the constructive reviews provided by Dr. Gaia Soldati and an anonymous reviewer. The authors acknowledge the data exchange between the Corinth Rift Laboratory network (CRL, http://crlab.eu/) and the Hellenic Unified Seismological Network (HUSN, http://www.gein.noa.gr/en/networks/husn). DG acknowledges the Erasmus Placement Program between the University of Patras (UPSL), École Normale Supérieure (ENS) and Institut de Physique du Globe de Paris (IPGP) for initializing this study. Most of the images were created using MatLab and the Generic Mapping Tool software (Wessel \& Smith 1998, http://www.soest.hawaii.edu/gmt/). 


\section{REFERENCES}

Armijo, R., Meyer, B., King, G., Rigo, A. \& Papanastassiou, D., 1996. Quaternary evolution of the Corinth Rift and its implications for the Late Cenozoic evolution of the Aegean. Geophys. J. Int., 126 (1), 11-53. doi:10.1111/j.1365-246X.1996.tb05264.x.

Avallone, A., Briole, P., Agatza-Balodimou, A.M., Billiris, H., Charade, O., Mitsakaki, C., Nercessian, A., Papazissi, K., Paradissis, D., \& Veis, G., 2004. Analysis of eleven years of deformation measured by GPS in the Corinth Rift Laboratory area. Comptes Rendus Geosciences 336 (4-5), 301-311. doi:10.1016/j.crte.2003.12.007.

Barmin, M., Ritzwoller, M. \& Levshin, A., 2001. A fast and reliable method for surface wave tomography. Monitoring the Comprehensive Nuclear-Test-Ban Treaty: Surface Waves. Springer, pp. 1351-1375.

Baud, P., Diraison, M., Geraud, Y., Reuschlé, T., Schmittbhul, J., Souque, C. \& Place, J., 2004. Circulation des fluides dans les systèmes de failles du Rift de Corinthe; Données structurales, pétrophysiques de porosité et de géochimie; rapport GDR "Corinth" (unpublished report, http://crllab.eu/).

Beckers, A., Hubert-Ferrari, A., Beck, C., Bodeux, S., Tripsanas, E., Sakellariou, D. \& De Batist, M., 2015. Active faulting at the western tip of the Gulf of Corinth, Greece, from high-resolution seismic data. Marine Geology, 360, 55-69.

Bell, R. E., McNeill, L. C., Bull, J. M. \& Henstock, T. J. 2008. Evolution of the offshore western Gulf of Corinth, Geol. Soc. Am. Bull., 120 (1-2), 156-178.

Bell, R.E., McNeill, L.C., Bull, J.M., Henstock, T.J., Collier, R.E.L. \& Leeder, M.R., 2009. Fault architecture, basin structure and evolution of the Gulf of Corinth Rift, central Greece. Basin Research 21 (6), 824-855. 
Bensen, G., Ritzwoller, M. \& Shapiro, N., 2008. Broadband ambient noise surface wave tomography across the united states, Journal of Geophysical Research : Solid Earth (1978-2012), 113 (B5), 1.

Bernard, P. et al., 1997. The Ms = 6.2, June 15, 1995 Aigion earthquake (Greece): Evidence for a lowangle normal faulting in the Corinth Rift, J. Seism., 1, 131-150.

Bernard, P. et al., 2006. Seismicity, deformation and seismic hazard in the western rift of Corinth: new insights from the Corinth Rift Laboratory (CRL). Tectonophysics, 426, 7-30.

Briole, P., Rigo, A., Lyon-Caen, H., Ruegg, J.C., Papazissi, K., Mitsakaki, C., Balodimou, A., Veis, G., Hatzfeld, D. \& Deschamps, A., 2000. Active deformation of the Corinth rift, Greece: results from repeated Global Positioning System surveys between 1990 and 1995. J. Geophys. Res. 105 (B11), 25605-25625. doi:10.1029/2000jb900148.

Bourouis, S. \& Cornet, F.H., 2009. Microseismic activity and fluid fault interactions: some results from the Corinth Rift Laboratory (CRL), Greece. Geophys. J. Int. 178 (1), 561-580. doi:10.1111/j.1365-246X.2009.04148.x.

Brenguier, F., Shapiro, N. M., Campillo, M., Nercessian, A. \& Ferrazzini, V., 2007. 3-D surface wave tomography of the Piton de la Fournaise volcano using seismic noise correlations, Geophysical Research Letters, 34 (2), L2305.

Brenguier, F., Campillo, M., Hadziioannou, C., Shapiro, N. M., Nadeau, R. \& Larose, E., 2008a. Postseismic relaxation along the San Andreas Fault at Parkfield from continuous seismological observations, Science, 321, 5895 1478-1481.

Brenguier, F., Shapiro, N. M., Campillo, M., Ferrazzini, V., Duputel, Z., Coutant, O. \& Nercessian, A., 2008b. Towards forecasting volcanic eruptions using seismic noise, Nature Geoscience, 1, 126130. 
Campillo, M. \& Paul, A., 2003. Long-range correlations in the diffuse seismic coda. Science, 299, 547-549.

Chouliaras, G., Kassaras, I., Kapetanidis, V., Petrou, P. \& Drakatos G., 2015. Seismotectonic analysis of the 2013 seismic sequence at the western Corinth Rift, Journal of Geodynamics, 90, 42-57, doi:10.1016/j.jog.2015.07.001.

Clarke, D., Zaccarelli, L., Shapiro, N.M. \& Brenguier F., 2011. Assessment of resolution and accuracy of the Moving Window Cross Spectral technique for monitoring crustal temporal variations using ambient seismic noise, Geophys. J. Int. 186 (2), 867-882.

Claerbout, J. F., 1968. Synthesis of a layered medium from its acoustic transmission response: Geophysics, 33, 264-269.

Corinth Rift Laboratory team and RESIF Datacenter, 2013. CL - Corinth Rift Laboratory Seismological Network (CRLNET); RESIF - Réseau Sismologique et géodésique Français. https://doi.org/10.15778/RESIF.CL

Cornet, F.L., Doan, M.L., Moretti, I. \& Borm, G., 2004. Drilling through the active Aigion fault: The AIG10 well observatory, C.R. Geos., 336 (4-5), 395-406.

Curtis, A., Gerstoft, P., Sato, H., Snieder, R. \& Wapenaar K., 2006. Seismic Interferometry - Turning Noise into Signal. The Leading Edge, Vol. 25(9), pp.1082-1092.

Doutsos, T. \& Kokkalas, S., 2001. Stress and deformation patterns in the Aegean region, J. Struct. Geol., 23, 455-472.

Doutsos, T. \& Poulimenos, G., 1992. Geometry and kinematics of active faults and their seismotectonic significance in the western Corinth-Patras rift (Greece). Journal of Structural Geology, 14 (6), 689-699. doi:10.1016/0191-8141(92)90126-h. 
Duverger, C., Godano, M., Bernard, P., Lyon-Caen, H. and Lambotte, S., 2015. The 2003-2004 seismic swarm in the western Corinth rift: Evidence for a multiscale pore pressure diffusion process along a permeable fault system, Geophys. Res. Lett., 42, 7374-7382, doi:10.1002/2015GL065298.

Flotté, N. \& Sorel, D., 2001. Structural cross-sections through the Corinth-Patras detachment faultsystem in northern Peloponnesus (Aegean arc Greece). Bull. Geol. Soc. Greece XXXIV (1), 235241.

Flotté, N., Sorel, D., Müller, C. \& Tensi, J., 2005. Along strike changes in the structural evolution over a brittle detachment fault: example of the Pleistocene Corinth-Patras rift (Greece). Tectonophysics 403, 77-94.

Ford, M., Rohais, S., Williams, E.A., Bourlange, S., Jousselin, D., Backert, N. \& Malartre, F., 2013. Tectono-sedimentary evolution of the western Corinth Rift (Central Greece). Basin Research 25 (1), 3-25.

Gautier, S., Latorre, D., Virieux, J., Deschamps, A., Skarpelos, C., Sotiriou, A., Serpetsidaki, A. \& Tselentis, A., 2006. A new passive tomography of the Aigion area (Gulf of Corinth, Greece) from the 2002 dataset, Pure Appl. Geophys., 163 (2), 431-453.

Godano, M., Deschamps, A., Lambotte, S., Lyon-Caen, H., Bernard P. \& Pacchiani, F., 2014. Focal mechanisms of earthquake multiplets in the western part of the Corinth Rift (Greece): influence of the velocity model and constraints on the geometry of the active faults, Geophys. J. Int. doi: 10.1093/gji/ggu059.

Hatzfeld, D, Kementzetzidou, D., Karakostas, V., Ziazia, M., Nothard, S., Diagourtas, D., Deschamps, A. Karakaisis, G., Papadimitriou, P., Scordilis, M., Smith, R., Voulgaris, N., Kiratzi, S., Makropoulos, K., Bouin, M.-P. \& Bernard, P., 1996. The Galaxidi earthquake of 18 November, 
1992: a possible asperity within the normal fault system of the Gulf of Corinth (Greece). Bull Seismol. Soc A., 86, 1987-1991.

Hatzfeld, D., Martinod, J., Bastet, G., \& Gautier, P., 1997. An analog experiment for the Aegean to describe the contribution of the gravitational potential energy. J. Geophys. Res., 102, 649-659.

Hatzfeld, D., Karakostas, V., Ziazia, M., Kassaras, I., Papadimitriou, E., Makropoulos, K., Voulgaris, N. \& Papaioannou, C., 2000. Microseismicity and faulting geometry in the Gulf of Corinth (Greece), Geophys. J. Int. 141, 438-456.

Hamelsdaël, R. \& Ford, M., 2014. Relay zone evolution: A history of repeated fault propagation and linkage, central Corinth rift, Greece, Basin Research, 27, doi: 10.1111/bre.12101.

Herrmann, R.B., 2013. Computer programs in seismology: an evolving tool for instruction and research. Seismol. Res. Lett. 84 (6), 1081-1088.

Jackson, J.A., 1994. Active tectonics of the Aegean region. Annu. Rev. Earth Planet. Sci. Lett., 22, $239-271$.

Jackson, J.A., Gagnepain, J., Houseman, G., King, G., Papadimitriou, P., Soufleris, P. \& Virieux, J., 1982. Seismicity, normal faulting and the geomorphological development of the Gulf of Corinth (Greece): the Corinth earthquakes of February and March 1981, Earth Planet. Sci. Lett. 57, 377 397.

Kao, H., Behr, Y., Currie, C.A., Hyndman, R., Townend, J., Lin, F.C., Ritzwoller, M.H., Shan, S.J. \& He J., 2013. Ambient seismic noise tomography of Canada and adjacent regions: Part I. Crustal structures, J. Geophys. Res. Solid Earth, 118, 5865-5887, doi:10.1002/2013JB010535.

Kapetanidis, V., Deschamps, A., Papadimitriou, P., Matrullo, E., Karakonstantis, A., Bozionelos, G., Kaviris, G., Serpetsidaki, A., Lyon-Caen, H., Voulgaris, N., Bernard, P., Sokos, E. \& Makropoulos, 
K., 2015. The 2013 earthquake swarm in Helike, Greece: seismic activity at the root of old normal faults. Geophys J Int, 202:2044-2073.

Karakostas, B., Papadimitriou, E., Hatzfeld, D., Makaris, D., Makropoulos, K., Diagourtas, D., Papaioannou, Ch., Stavrakakis, G., Drakopoulos, J. \& Papazachos, B., 1994. The aftershock sequence of July 14, $1993\left(M_{S}=5.4\right)$ Patras earthquake. In: Seventh congress of geological society, Greece, XXX/5:167-174.

King, G.C.P., Ouyang, Z.X., Papadimitriou P., Deschamps, A., Gagnepain, J., Houseman, G., Jackson, J.A., Soufleris, C. \& Virieux, J., 1985. The evolution of the Gulf of Corinth (Greece): an aftershock study of the 1981 earthquakes, Geophys. J. R. Astr. Soc., 80, 677-683.

Koukouvelas, I.K. \& Papoulis, D., 2009. Fluid involvement in the Helike normal fault, Gulf of Corinth Greece, J. Struct. Geol. 31, 237-250.

Lambotte S., Lyon-Caen, H., Benard, P., Deschamps, A., Patau, G., Nercessian, A., Pacchiani, F., Bourouis, S., Drilleau M. \& Adamova, P., 2014. Reassessment of the rifting process in the Western Corinth Rift from relocated seismicity, Geophys. J. Int., doi: 10.1093/gji/ggu096.

Latorre, D., Virieux, J., Monfret, T., Monteiller, V., Vanorio, T., Got, J.L. \& Lyon-Caen, H., 2004. A new seismic tomography of Aigion area (Gulf of Corinth, Greece) from the 1991 data set. Geophysical Journal International 159 (3), 1013-1031.

Leeder, M. R., Mark, D.F., Gawthorpe, R.L., Kranis, H., Loveless, S., Pedentchouk, N., Skourtsos, E., Turner, J., Andrews, J.E. \& Stamatakis, M., 2012. A “Great Deepening”: Chronology of rift climax, Corinth rift, Greece, Geology, 40 (11).

Le Pichon, X. \& Angelier, J., 1979. The Hellenic arc and trench system: a key to the neotectonic evolution of the eastern Mediterranean area. Tectonophysics, 60, 1-42. 
Le Pichon, X., Chamot-Rooke, N., Lallemant, S., Noomen, R. \& Veis, G., 1995. Geodetic determination of the kinematics of the central Greece with respect to Europe: Implication for eastern Mediterranean tectonics, J. Geophys. Res., 100, 12 675-12 690.

Levshin, A., Yanovskaya, T., Lander, A., Bukchin, B., Barmin, M., Ratnikova, L. \& Its E., 1989. Seismic Surface Waves in a Laterally Inhomogeneous Earth, (ed. V.I. Keilis-Borok) Kluwer Pupl., Dordrecht.

Lobkis, O. I. \& Weaver, R. L., 2001. On the emergence of the Green's function in the correlations of a diffuse field: J. Acoust. Soc. Am., 110, 3011-3017.

Lowrie, W., 2007. Fundamentals of Geophysics, $2^{\text {nd }}$ edn, Cambridge University Press.

Lykousis, V., Sakellariou, D., Moretti, I. \& Kaberi H., 2007. Late Quaternary basin evolution of the Gulf of Corinth: Sequence stratigraphy, sedimentation, fault-slip and subsidence rates, Tectonophysics, 440 (1-4), 29-51.

Lyon-Caen, H., Papadimitriou, P., Deschamps, A., Bernard, P., Makropoulos, K., Pacchiani, F. \& Patau, G., 2004. First results of CRLN seismic array in the western Corinth rift: evidence for old fault reactivation, C.R. Geoscience, 336, 343-352.

McClusky, S. et al., 2000. Global Positioning System constraints on the plate kinematics and dynamics in the eastern Mediterranean and Caucasus. J. Geophys. Res., 105, 5695-5719.

McNeill, L.C., Cotterill, C.J., Henstock, T.J., Bull, J.M., Stefatos, A., Collier, R.E.L., Papatheoderou, G., Ferentinos, G., Hicks, S.E., 2005. Active faulting within the offshore western Gulf of Corinth, Greece: implications for models of continental rift deformation. Geology, 33 (4), 241.

Micarelli, L., Moretti, I. \& Daniel, J.M., 2003. Structural properties of rift-related normal faults: the case study of the Gulf of Corinth, Greece. J. Geodyn. 36, 275-303. 
Moschetti, M.P., Ritzwoller, M.H. \& Shapiro, N.M., 2007. Surface wave tomography of the western United States from ambient seismic noise: Rayleigh wave group velocity maps. Geochem. Geophys. Geosyst., 8 (Q08010).

Mordret, A., Landès, M., Shapiro, N.M., Singh, S., Roux, P. \& Barkved, O., 2013. Near-surface study at the Valhall oil field from ambient noise surface wave tomography. Geophys. J. Int. 193 (3), $1627-1643$.

Mordret, A., Landès, M., Shapiro, N.M., Singh, S. \& Roux, P., 2014. Ambient noise surface wave tomography to determine the shallow shear velocity structure at Valhall: depth inversion with a Neighbourhood Algorithm. Geophys. J. Int. 198 (3), 1514-1525.

Mordret, A., Rivet, D., Landès, M. \& Shapiro, N.M., 2015. 3-D shear-velocity anisotropic model of Piton de la Fournaise volcano (la Réunion island) from ambient seismic noise. J. Geophys. Res. Solid Earth 120 (1), 406-427.

Nixon, C. W., Mcneill, L. C., Bull, J. M., Bell, R. E., Gawthorpe, R. L., Henstock, T. J., Christodoulou, D., Ford, M., Taylor, B., Sakellariou, D., Ferentinos, G., Papatheodorou, G., Leeder, M., R., Collier, R. E. Li., Goodliffe, A., M., Sachpazi, M. \& Kranis, H., 2016. Rapid spatiotemporal variations in rift structure during development of the Corinth Rift, central Greece. Tectonics, 35 (5), 1225-1248.

Novotny O., Zahardnik, J. \& Tselentis G-A., 2000. NW Turkey Earthquakes and the crustal structure inferred from surface waves observed in the Corinth Gulf, Greece. Bulletin of the Seismological Society of America, 91, 4, 875-879.

Obermann, A., Lupi, M., Mordret, A., Jakobsdóttir, S. \& Miller, S., 2016. 3D-ambient noise Rayleigh wave tomography of Snæfellsjökull volcano, Iceland, Journal of Volcanology and Geothermal Research, 317, 42-52. 
Pacchiani, F. \& Lyon-Caen, H., 2010. Geometry and spatio-temporal evolution of the 2001 Agios Ioanis earthquake swarm (Corinth Rift, Greece), Geophys. J. Int., 180 (1), 59-72.

Palyvos, N., Lemeille, F., Sorel, D., Pantosti, D. \& Pavlopoulos, K., 2008. Geomorphic and biological indicators of paleoseismicity and Holocene uplift rate at a coastal normal fault footwall (western Corinth Gulf, Greece). Geomorphology 96 (1-2), 16-38.

Papadopoulos, G. A., 2000. A new tsunami catalogue of the Corinth Rift: 373 B.C.-A.D. 2000. In: G. A. Papadopoulos (ed.), Historical Earthquakes and Tsunamis in the Corinth Rift, Central Greece, Inst. Geodynamics, Natl. Observatory Athens, pp. 121-126.

Pik, R. \& Marty, B., 2009. Helium isotopic signature of modern and fossil fluids associated with the Corinth rift fault zone (Greece): Implication for fault connectivity in the lower crust, Chemical Geol., 266, 67-75.

Rigo, A., Lyon-Caen, H., Armijo, R., Deschamps, A., Hatzfeld, D., Makropoulos, K., Papadimitriou, P. \& Kassaras, I., 1996. A microseismic study in the western part of the Gulf of Corinth (Greece): implications for large-scale normal faulting mechanisms. Geophys. J. Int. 126 (3), 663-688.

Ritzwoller, M., Lin, F. \& Shen, W., 2011. Ambient noise tomography with a large seismic array. Compt. Rendus Geosci., 343 (8), 558-570.

Roberts, G. P., Houghton, S. L., Underwood, C., Papanikolaou, I., Cowie, P.A., van Calsteren, P., Wigley, T., Cooper, F.J. \& McArthur J.M., 2009. Localization of Quaternary slip rates in an active rift in 105 years: An example from central Greece constrained by 234 U- 230 Th coral dates from uplifted paleoshorelines, J. Geophys. Res., 114 (B10), B10406.

Sabra, K., Gerstoft, P., Roux, P., Kuperman, W. \& Fehler, M., 2005. Surface wave tomography from microseisms in Southern California, Geophys. Res. Lett., 32 L14311. 
Sachpazi M., Christophe Clement, C., Laigle, M., Hirn H. \& Roussos, N., 2003. Rift structure, evolution, and earthquakes in the Gulf of Corinth, from reflection seismic images. Earth and Planetary Science Letters 216, 243-257.

Sambridge, M., 1999a. Geophysical inversion with a neighborhood algorithm. I. Searching a parameter space. Geophys. J. Int., 138 (2), 479-494.

Sambridge, M., 1999b. Geophysical inversion with a Neighbourhood Algorithm -II. Appraising the ensemble. Geophys. J. Int., 138, 727-746.

Shapiro, N.M. \& Campillo, M., 2004. Emergence of broadband Rayleigh waves from the correlations of ambient seismic noise. Geophys. Res. Lett., 31 (L07614).

Shapiro, N. M., Campillo, M., Stehly, L. \& Ritzwoller, M.H., 2005. High resolution surface-wave tomography from ambient seismic noise: Science, 307, 1615-1618.

Sokos E, Zahradník, J., Kiratzi, A., Janský, J., Gallovič, F., Novotny, O., Kostelecký, J., Serpetsidaki, A. \& Tselentis, G-A., 2012. The January 2010 Efpalio earthquake sequence in the western Corinth Gulf (Greece). Tectonophysics 530-531:299-309, doi:10.1016/j.tecto.2012.01.005.

Sorel, D., 2000. A Pliocene and still-active detachment fault and the origin of the Corinth-Patras rift, Greece, Geology, 28, 83-86.

Taylor B., Weiss, J. R., Goodliffe, A., Sachpazi, M., Laigle M. \& A. Hirn, A., 2011. The structures, stratigraphy and evolution of the Gulf of Corinth rift, Greece, Geophys. J. Int., 185, 1189-1219.

Tselentis, G., Melis, N. \& Sokos, E., 1994. The Patras (July 14, 1993; Ms = 5.4) earthquake sequence. In: Seventh congress geological society, Greece XXX/5:159-166.

Tselentis, G., Melis, N., Sokos, E. \& Papatsimpa, K., 1996. The Egion June 15, 1995 (6.2 Ml) earthquake, Western Greece, Pure App. Geophys. 147, 83-98. 
Wapenaar, K., 2004. Retrieving the elastodynamic Green's function of an arbitrary inhomogeneous medium by cross correlation. Phys. Rev. Lett. 93 (25), 254-301.

Wessel, P. \& Smith, W.H.F., 1998. New improved version of the Generic Mapping Tools Released, EOS, Trans. Am. geophys. Un., 79, 579.

Yang, Y., Ritzwoller, M. H., Lin, F.-C., Moschetti, M. \& Shapiro, N. M., 2008. Structure of the crust and uppermost mantle beneath the western United States revealed by ambient noise and earthquake tomography, Journal of Geophysical Research: Solid Earth (1978-2012), 113, B12310, doi: 10.1029/2008JB005833.

Yao, H., 2015. A method for inversion of layered shear wavespeed azimuthal anisotropy from Rayleigh wave dispersion using the Neighborhood Algorithm, Earthq Sci, 28 (1), 59-69. doi:10.1007/s11589-014-0108-6

Zelt, B.C., Taylor, B. M., Sachpazi, M. \& Hirn, A., 2005. Crustal velocity and Moho structure beneath the Gulf of Corinth, Greece, Geophys. J. Int., 162, 257-268 doi: 10.1111/j.1365-246X.2005.02640. 


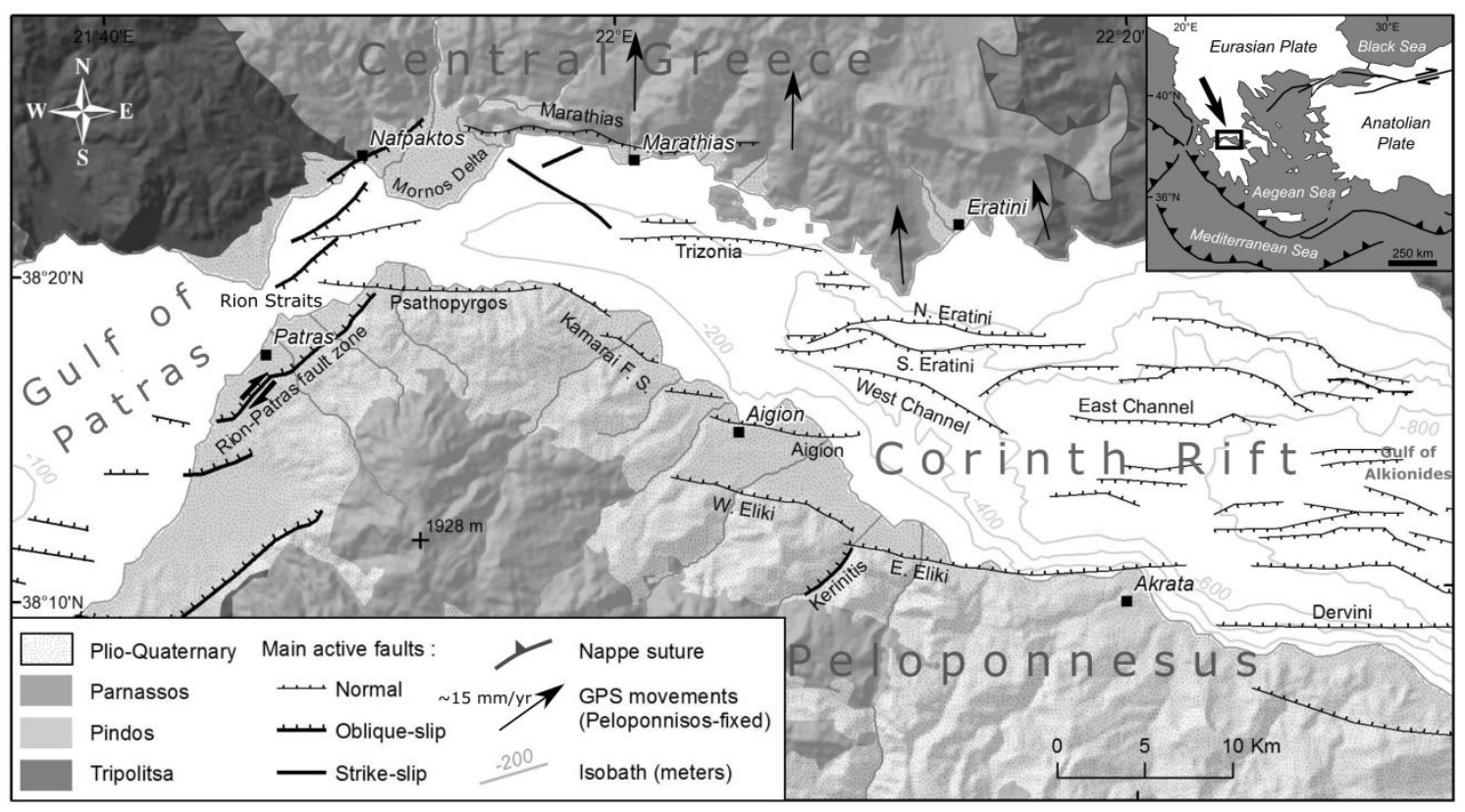

Fig. 1: Tectonic map of the western Corinth Rift modified from Beckers et al. (2015). Major on-shore and off-shore fault traces of the area as in Ford et al. (2013), Palyvos et al. (2008), Flotté et al. (2005), McNeill et al. (2005), Bell et al. (2009), and Taylor et al. (2011). GPS displacement vectors from Avallone et al. (2004). 


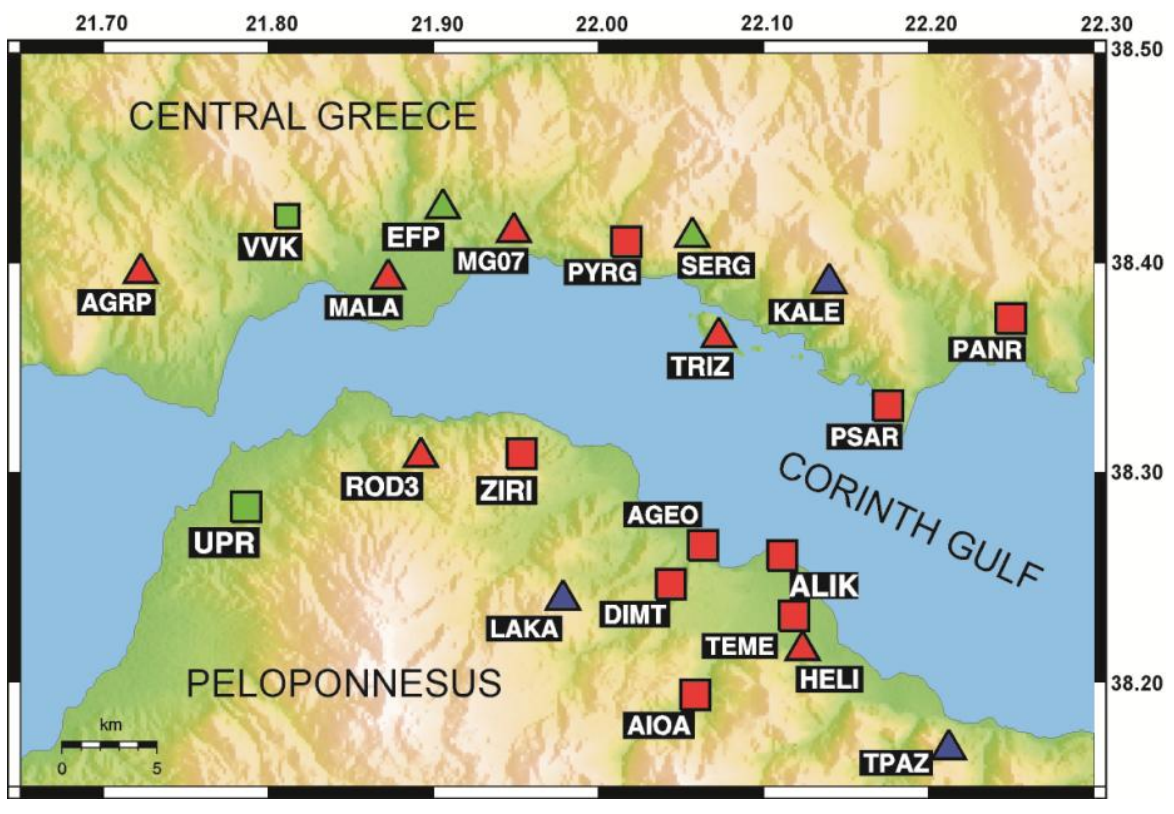

Fig. 2: Map of the western Corinth Rift and seismic stations used in this study. Broadband seismometers are displayed with triangles and short-period seismometers are displayed with rectangles, where red, blue and green colors signify stations operated by the Corinth Rift Laboratory (CRL, http://crlab.eu/), the Seismological Laboratory of Athens University (NKUA, http://dggsl.geol.uoa.gr/) and the University of Patras Seismological Laboratory (UPSL, http://seismo.geology.upatras.gr/), respectively. 

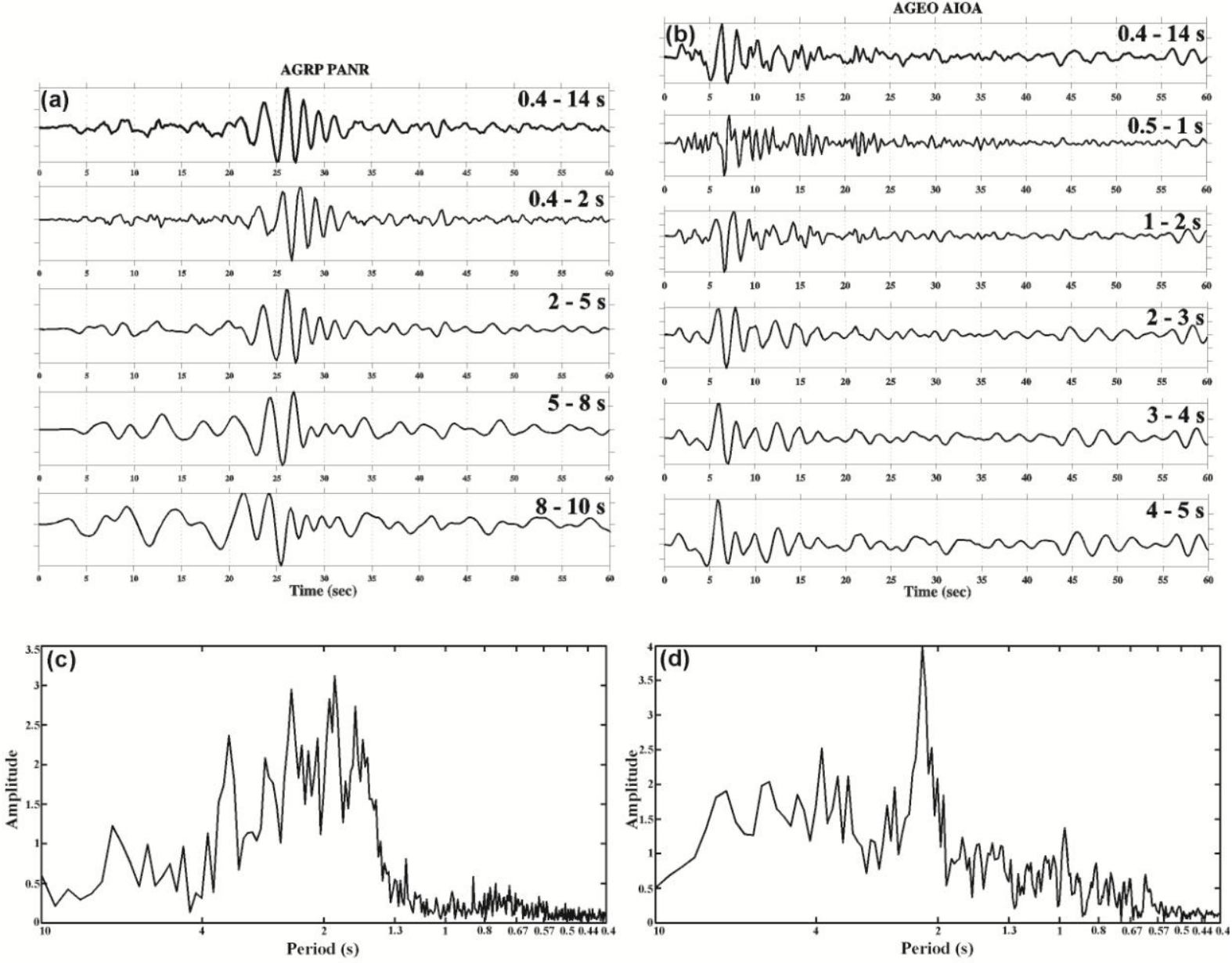

Fig. 3: Cross-correlations between (a) AGRP and PANR stations and between (b) AGEO and AIOA stations from $\sim 3$ yrs of ambient noise filtered for different period bands and computed for the vertical components of noise records. (c) and (d) amplitude spectra of AGRP and PANR, and AGEO and AIOA cross-correlations. 


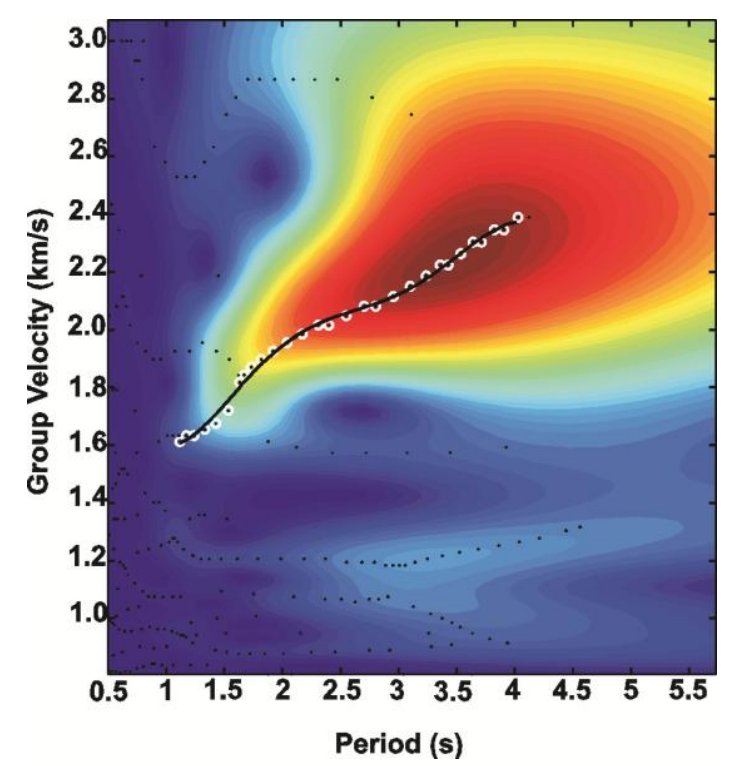

Fig. 4: An example of dispersion curve automatic picking on the frequency-time (periodvelocity) diagrams for vertical-vertical component correlation between the stations EFP and PSAR. The colored background represents the time-frequency diagram with the warm colors showing the large amplitudes. Black dots represent the relative maxima of the diagram, while the white circles highlight the automatic picking of these points. The black line is a five-order polynomial fitting to the automatic picks. 


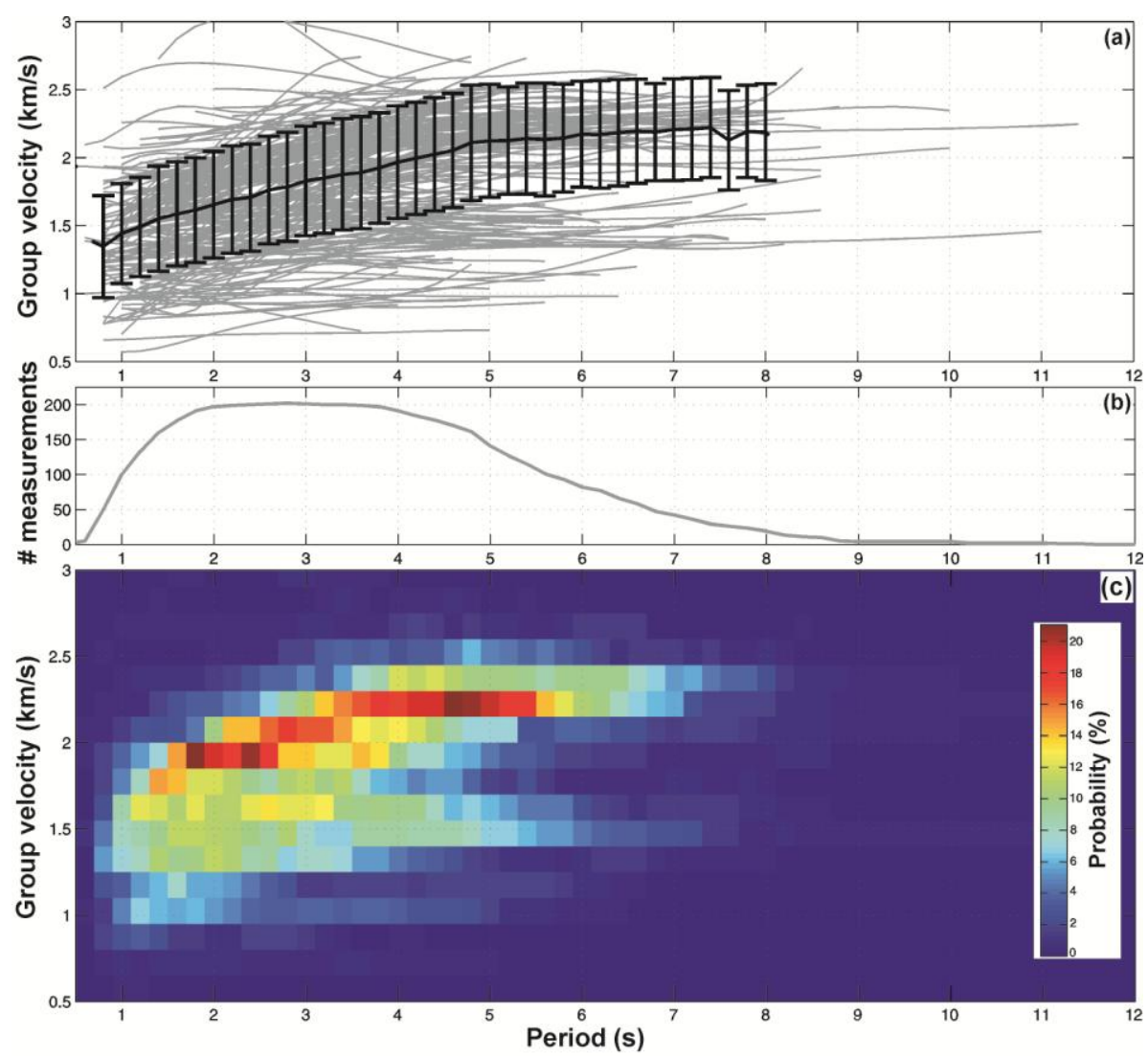

Fig. 5: (a) Every Rayleigh-wave dispersion curve measured in this study is plotted on a frequency-time diagram. The average dispersion curve with its standard deviation is plotted as thick black line. (b) A diagram showing the number of measurements as a function of the period and (c) a probability density function plot of the dispersion curves. 

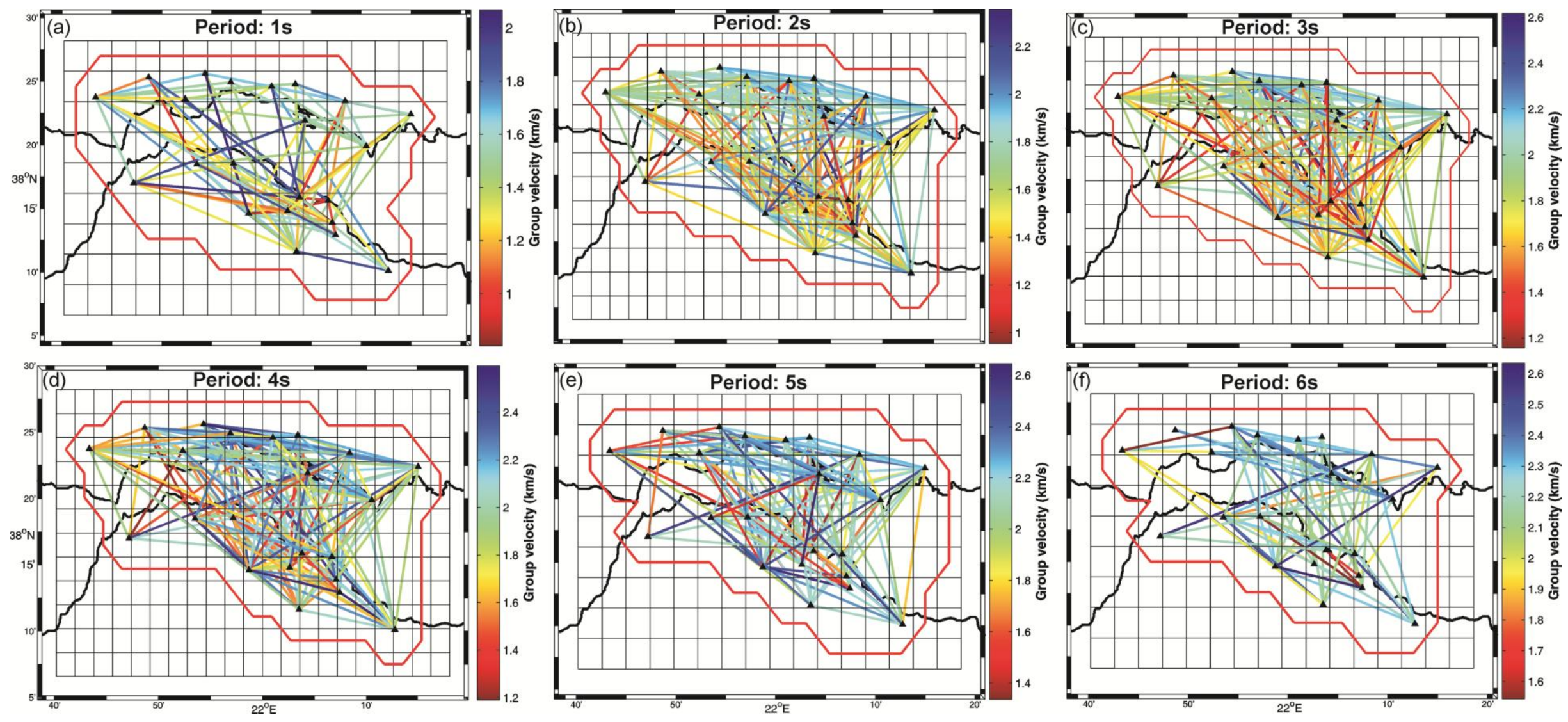

Fig. 6: Rayleigh-wave group velocity measurements and ray-path coverage at $1 \mathrm{~s}, 2 \mathrm{~s}, 3 \mathrm{~s}, 4 \mathrm{~s}, 5 \mathrm{~s}$ and 6 s, respectively. The thick red line shows the limit of the study area connecting cells of the geographical grid with no measurements. Seismic stations are shown as black triangles. 


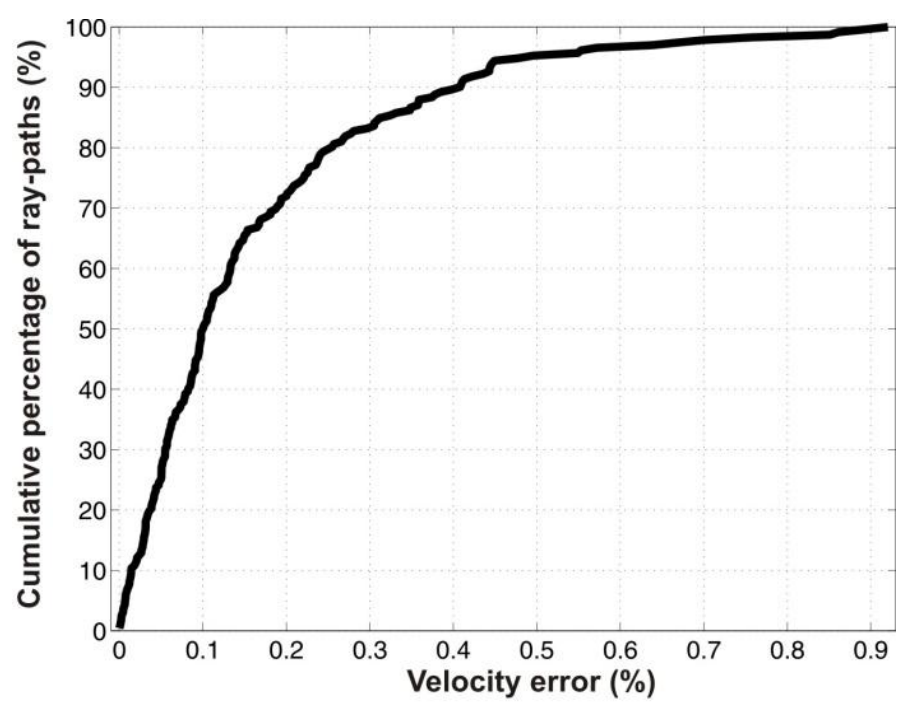

Fig. 7: Velocity error introduced by excluding the topography and the bathymetry of the study area. The black curve shows the cumulative number of ray-paths with errors smaller than a certain threshold. $100 \%$ of the inter-station paths have error smaller than $1 \%$, while the $90 \%$ of them has errors smaller than $0.5 \%$. 


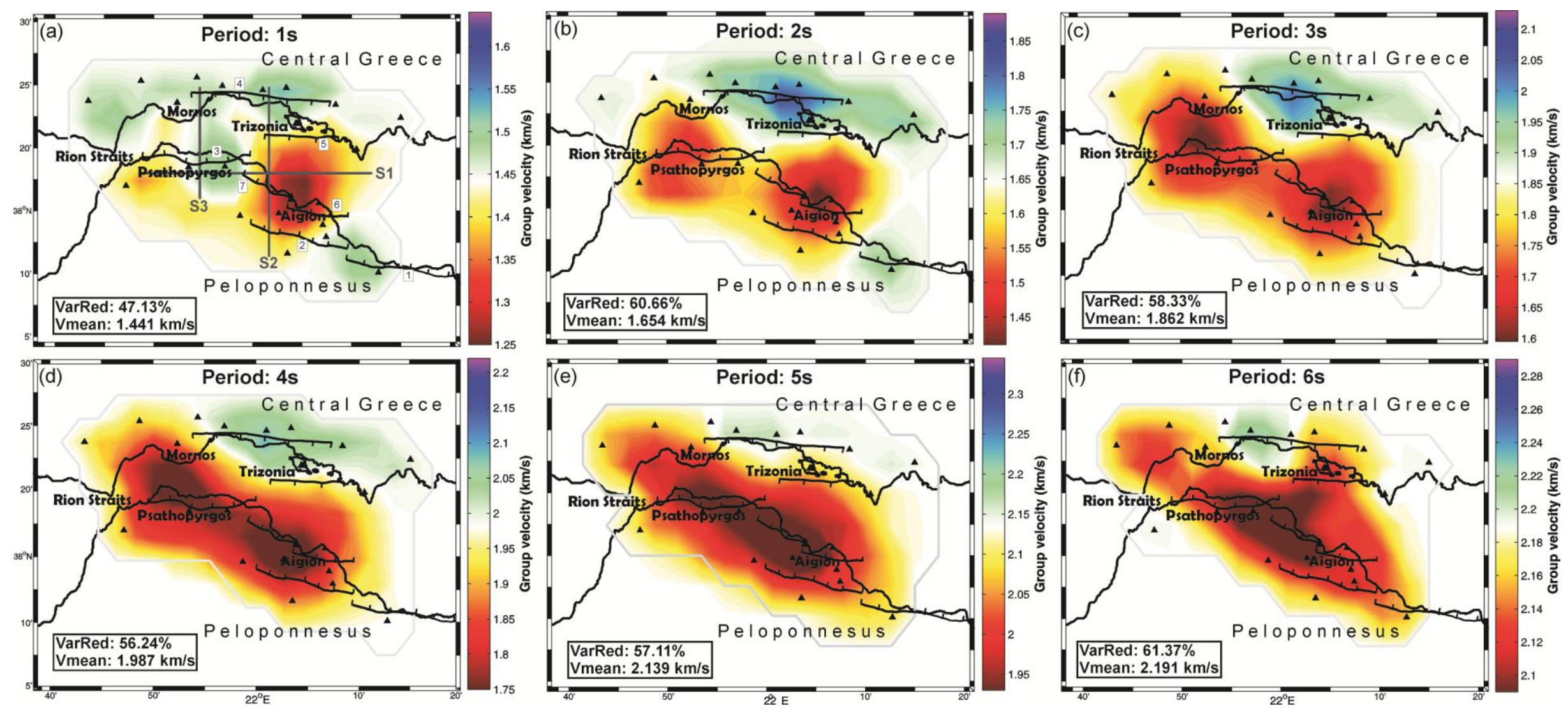

Fig. 8: Rayleigh-wave group velocity maps at 1 s, 2 s, 3 s, 4 s, 5 s and 6 s. Seismic stations are shown as black triangles. For each period, the variance reduction (VarRed) between data computed from a homogeneous model with an average velocity and the final model, as well as the final mean velocity (Vmean) are shown at the lower left corner of each frame. Major fault traces shown are: 1=East Eliki, 2=West Eliki, 3=Psathopyrgos, 4=Marathias, 5=Trizonia, 6=Aigion, 7=Kamarai/Selianitika. The respective fault numbers are shown in 8a. The thick grey lines (8a) denote examples of extracted 2D profiles (S1, S2 and S3) at depth shown in Fig. 12. 


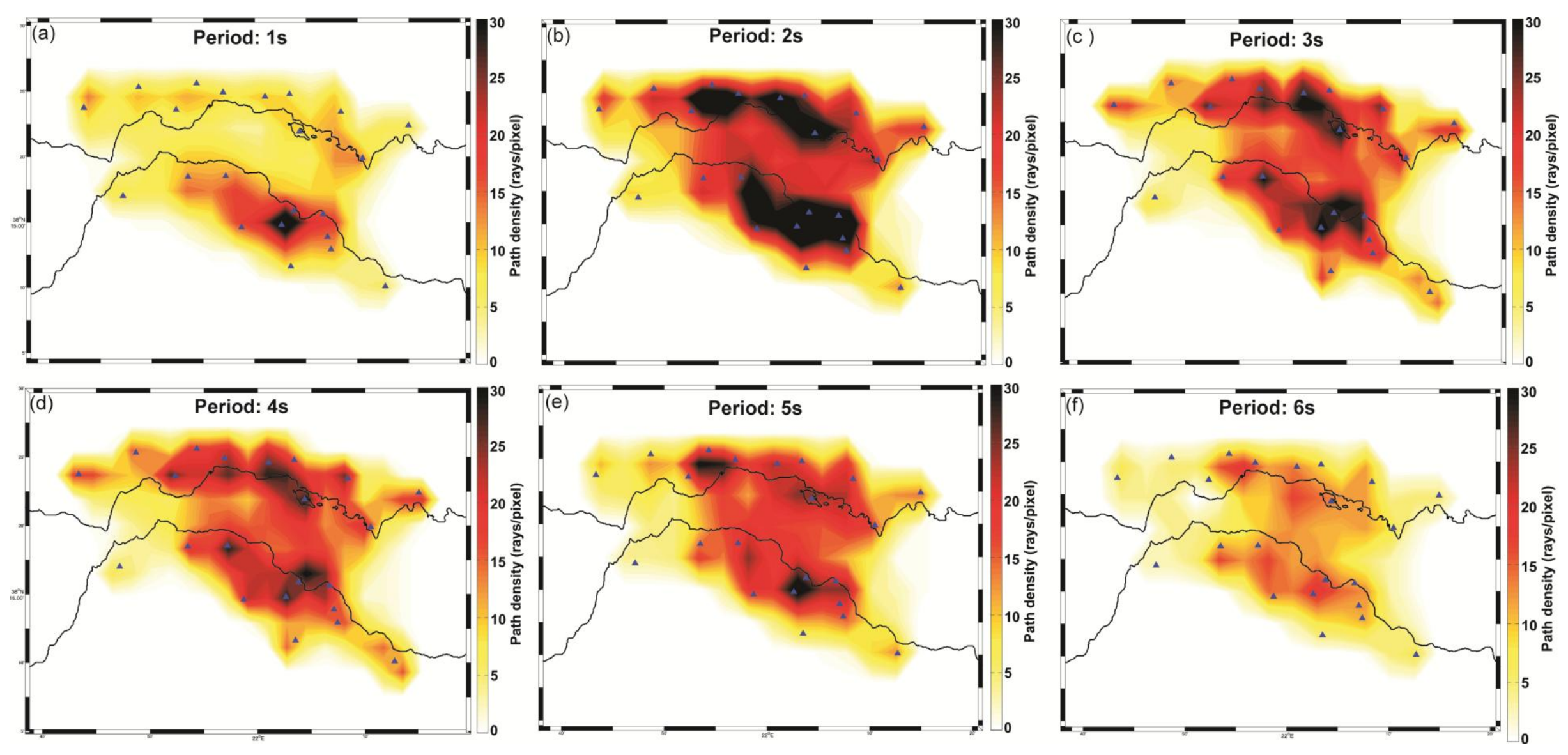

Fig. 9: The ray-path density at 1 s, 2 s, 3 s, 4 s, 5 s and 6 s. Seismic stations are shown as blue triangles. 

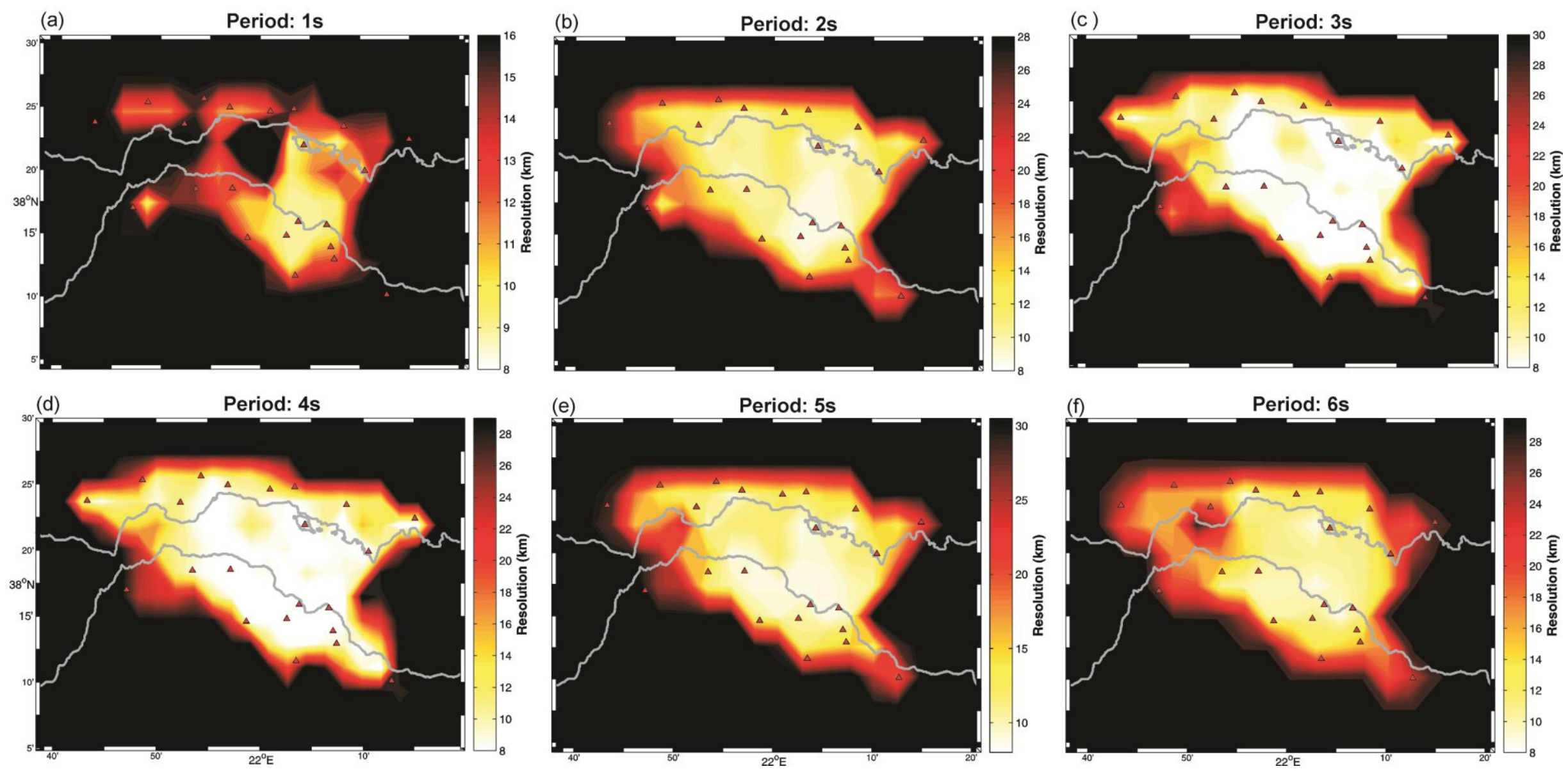

Fig. 10: Spatial resolution maps at 1 s, 2 s, 3 s, 4 s, 5 s and 6 s. Seismic stations are shown as red triangles. 

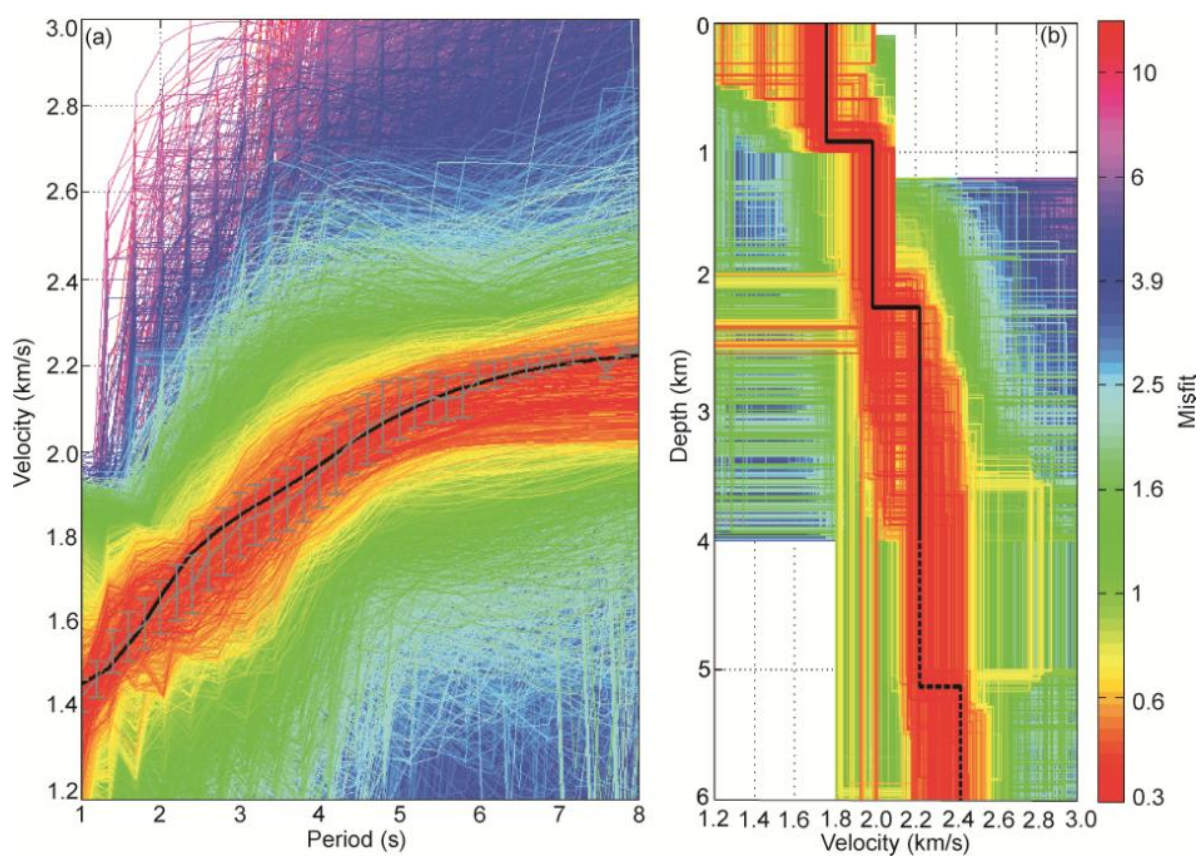

Fig. 11: Inverted shear-wave velocity model for the whole study area. (a) Synthetic dispersion curves overlaid by the average local dispersion curve with error bars. The thick black line is the dispersion curve with the minimum misfit value and (b) the associated inverted models. The thick black line is the model with the minimum misfit value while the well and poorly resolved parts are shown with solid and dashed line, respectively. Both synthetic dispersion curves and models are colored according to their misfit. 


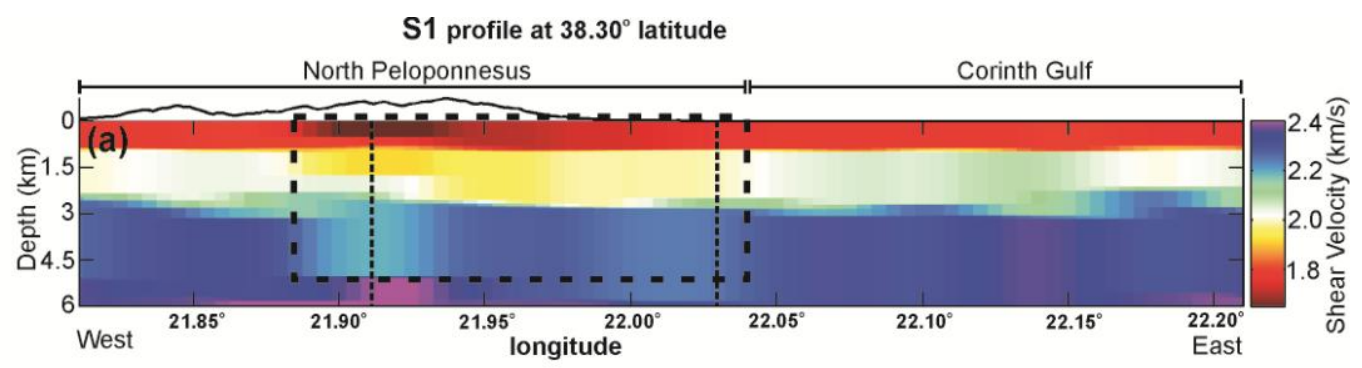

$\mathrm{S} 2$ profile at $22.03^{\circ}$ Iongitude

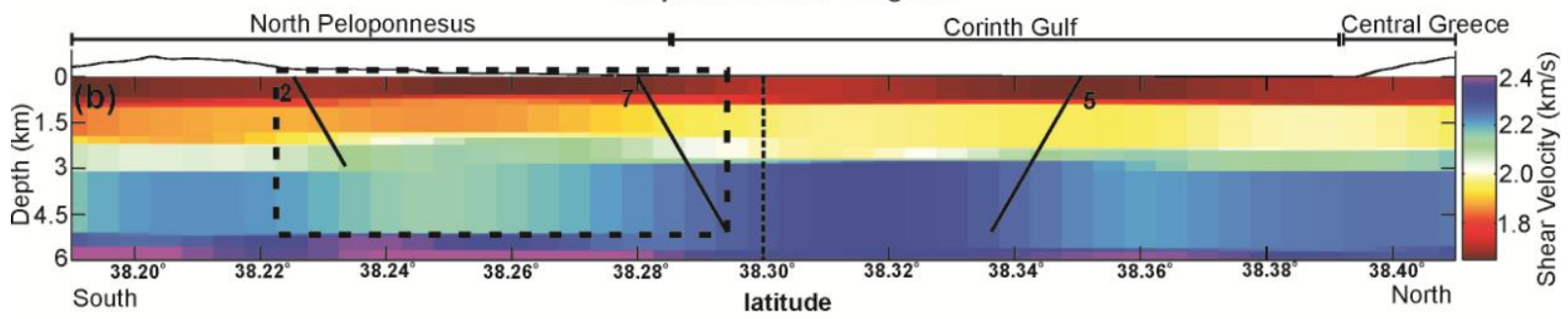

S3 profile at $21.91^{\circ}$ Iongitude

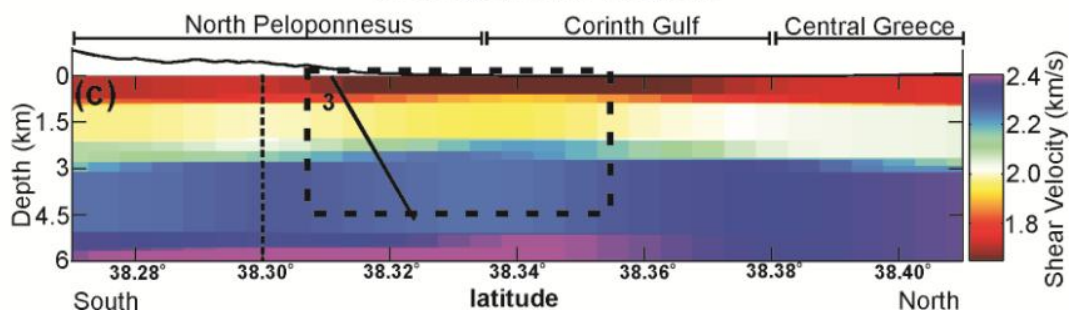

Fig. 12: Vertical cross-sections along the grey lines sketched in Fig. 8a according to the results of the depth inversion. The thick dashed black lines show the intersection between the profiles. Major fault traces shown are: 2=West Eliki, 3=Psathopyrgos, 5=Trizonia, 7=Kamarai/Selianitika. Major faults (black lines) are presented and numbered as in Fig. 8a. The faults geometry approximation is taken from Bernard et al. (2006). Dashed rectangles indicate the relative expansion of the most significant low velocity regions. 

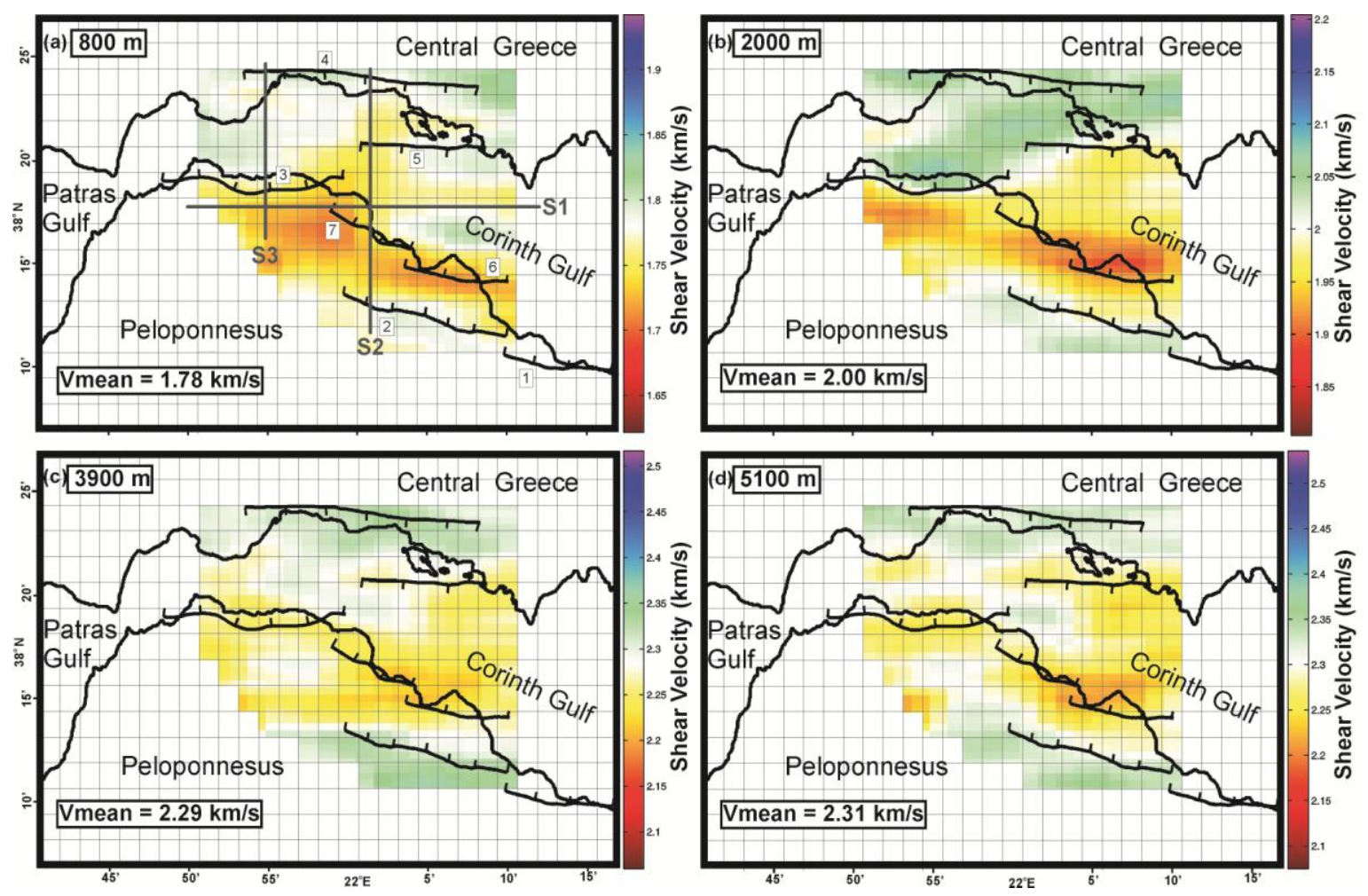

Fig. 13: Slices through the 3D shear-velocity models at (a) $800 \mathrm{~m}$, (b) $2000 \mathrm{~m}$, (c) $3900 \mathrm{~m}$ and (d) $5100 \mathrm{~m}$ below the sea level. The colorbars are limited between values that deviate $+10 \%$ and $-10 \%$ from the mean shear-velocity values. Major fault traces shown are: 1=East Eliki, 2=West Eliki, 3=Psathopyrgos, 4=Marathias, 5=Trizonia, 6=Aigion, 7=Kamarai/Selianitika. 


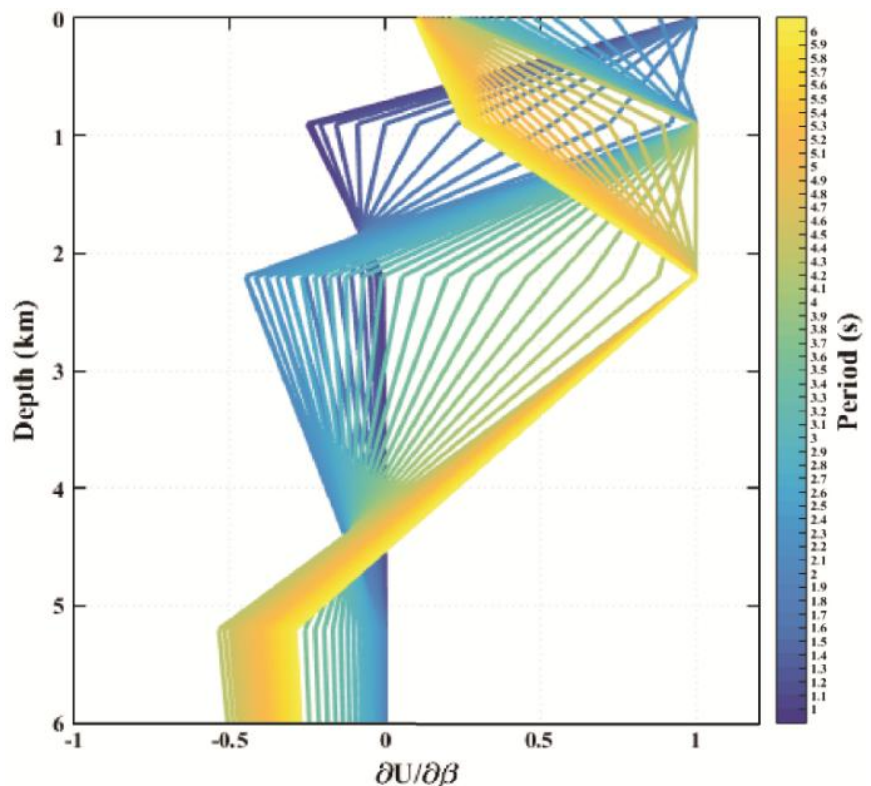

Fig. 14: Depth sensitivity kernel at different periods between 1 and $6 \mathrm{~s}$ computed from the average 1D velocity profile obtained for the western Corinth Rift (Fig. 11). 


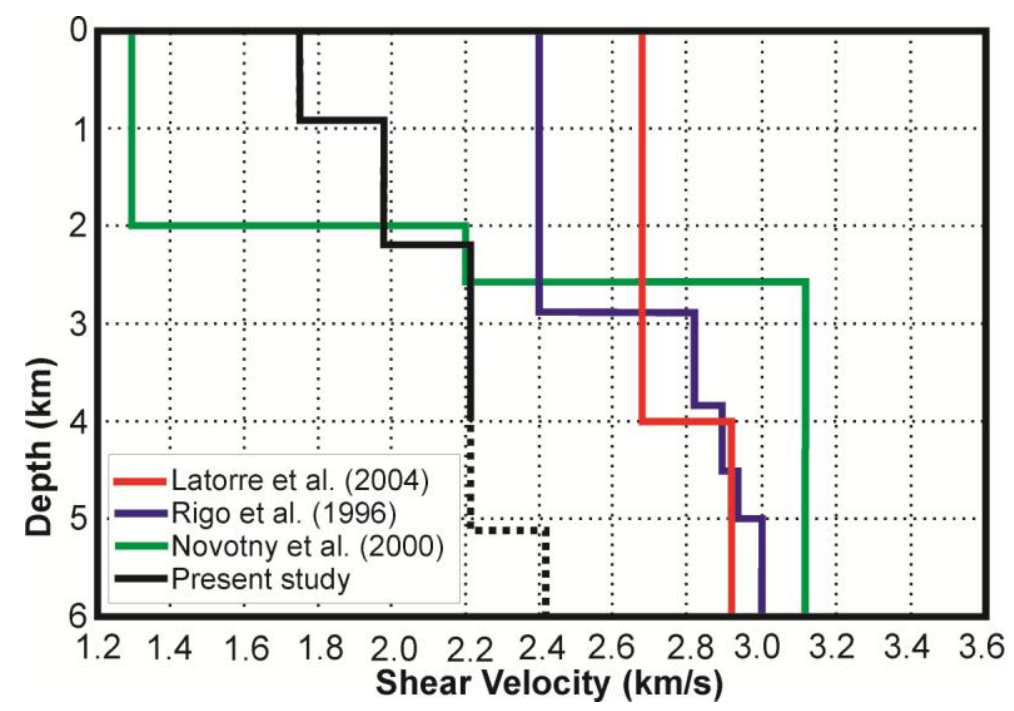

Fig. 15: Superposition of the average 1D Vs model derived from the present study and the three crustal models proposed for the western Corinth Rift by Latorre et al. (2004), Rigo et al. (1996) and Novotny et al. (2000). The well and poorly resolved parts of the average 1D Vs model derived from the present study are shown with solid and dashed line, respectively. 
(a)
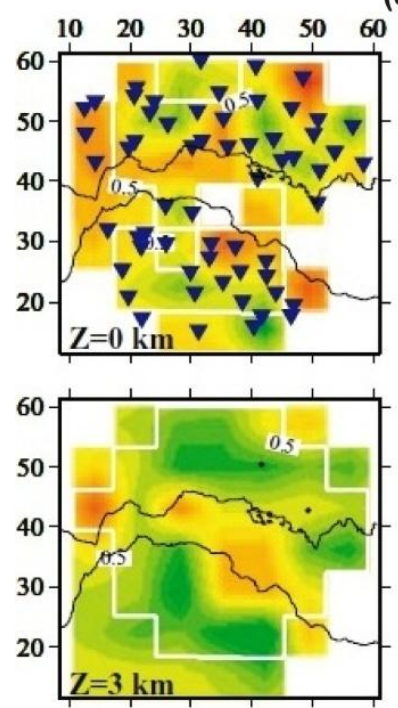
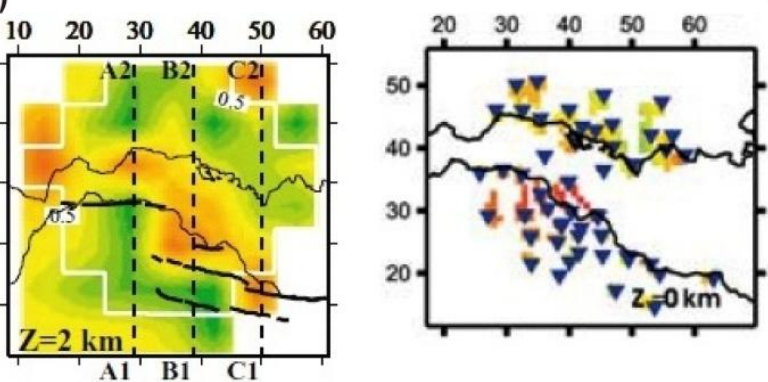

(b)
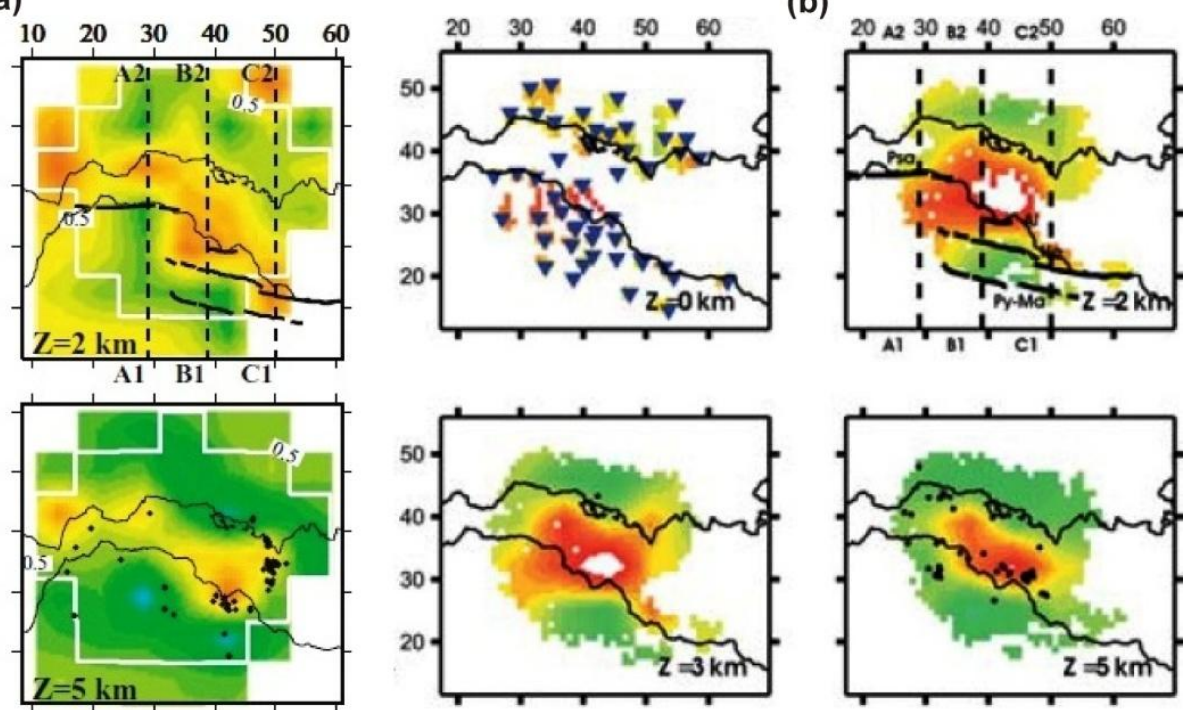

Fig. 16: Tomographic models of shear-wave velocities in the western Corinth Rift derived by (a) Latorre et al. (2004) and (b) Gautier et al. (2006). Map views show velocity layers between 0 and $5 \mathrm{~km}$ depth. Stations are plotted as triangles and major faults are drawn in dark lines (Psa: Psathopyrgos fault; Ai: Aigion fault; He: Heliki fault and Py-Ma: PyrgakiMamoussia fault). Figure modified from Latorre et al. (2004) and Gautier et al. (2006). 